\title{
Experimental analysis and design strength models adopted by international guides for FRP-confined concrete columns subjected to axial compression
}

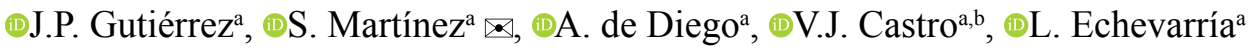 \\ a. Eduardo Torroja Institute for Construction Sciences (IETcc, CSIC), (Madrid, Spain) \\ b. School of Civil Engineering, Universidad Politécnica de Madrid (UPM), (Madrid, Spain) \\ soniamdm@ietcc.csic.es
}

Received 28 July 2021

Accepted 21 september 2021

Available on line 12 november 2021

\begin{abstract}
Carbon fiber jacketing is an efficient technique for increasing the strength and strain capacity of concrete circular and square section columns subjected to axial load, although confinement efficiency decreases for rectangular cross-section members. The research project BIA 2016-80310-P includes an experimental program on intermediate-size plain concrete specimens strengthened with carbon fiber jackets, mostly with square and rectangular cross-sections. The results, alongside others with similar characteristics from two databases published, are compared to predictions of four international guides. The incidence of the key parameters in the experimental results is analyzed, such as the aspect ratio of the section, the effective strain in FRP jacket attained at failure or the rounded corner radius. As a result, two efficiency strain factors are proposed, one for circular and another for rectangular specimens. The predictions contained in certain guides, based on a simple linear design-model, are improved by using the proposed efficiency strain factor for rectangular sections.
\end{abstract}

KEYWORDS: Concrete; Composite materials; Compressive strength; Confinement; Structural strengthening.

Citation/Citar como: Gutiérrez, J.P.; Martínez, S.; de Diego, A.; Castro, V.J.; Echevarría, L. (2021) Experimental analysis and design strength models adopted by international guides for FRP-confined concrete columns subjected to axial compression. Mater. Construcc. 71 [344], e266. https://doi.org/10.3989/mc.2021.11521.

RESUMEN: Análisis experimental y modelos de resistencia adoptados por distintas guías internacionales para pilares de hormigón confinados con FRP sometidos a compresión centrada. El refuerzo con encamisados de fibra de carbono es una técnica eficaz para aumentar la resistencia y la capacidad de deformación de pilares de hormigón de sección circular y cuadrada sometidos a carga axial, si bien la eficiencia del confinamiento disminuye en elementos de sección rectangular. El proyecto de investigación BIA 2016-80310-P incluye un programa experimental sobre probetas de hormigón en masa de tamaño intermedio reforzadas con camisas de fibra de carbono, en su mayor parte de sección cuadrada y rectangular. Los resultados obtenidos, junto con los de otros ensayos de características similares incluidos en dos bases de datos publicadas, se comparan con las predicciones de cuatro guías internacionales. Se analiza la incidencia de parámetros claves en los resultados experimentales, tales como la relación de aspecto entre lados de la sección, la deformación efectiva de la camisa en la rotura o el radio de redondeo de la esquina. Como resultado, se proponen dos factores de eficiencia de deformación, uno para probetas circulares y otro para rectangulares. Las predicciones de alguna de las guías, basadas en modelos de diseño de tipo lineal simple, mejoran al emplear el factor de eficiencia de deformación propuesto para secciones rectangulares.

PALABRAS CLAVE: Hormigón; Materiales compuestos; Resistencia a compresión; Confinamiento; Refuerzo estructural.

Copyright: (C2021 CSIC. This is an open-access article distributed under the terms of the Creative Commons Attribution 4.0 International (CC BY 4.0) License. 


\section{INTRODUCTION}

Nowadays there is an ever increasing need to reuse/ recycle existing means. This also occurs in the construction field where numerous ageing buildings and infrastructures need to be upgraded. Fiber reinforced polymers (FRPs) feature excellent properties for use as structural strengthening. Among others, the use of FRP jackets has proven to be an effective technique to improve the resistance and strain capacity of reinforced concrete (RC) members subjected to axial compression (1). The grounding of this reinforcement technique by FRP confinement is widely known. In a column subjected to axial load, the concrete dilates laterally, and this expansion is restrained by the external FRP jacket that provides a confining pressure acting on the concrete core. Unlike steel, FRPs are linear elastic materials and confinement pressure can increase up to the failure point. Failure occurs, mainly, due to tensile failure of the fibers of the jacket. The axial stress-strain behavior of FRP-confined concrete follows an approximately bi-linear ascending response when sufficient amount of reinforcement is applied.

Numerous experimental studies have been carried out on the behavior of FRP-confined concrete, most of them on small circular section specimens (2-3). Although to a lesser extent, tests have also been performed on non-circular section specimens, where confinement is less efficient (4-8). The lower efficiency for rectangular cross-section is due to the confining action seem to be focused mainly at the corners rather than around the entire perimeter, meaning the confining stress field is non-uniform (9-14).

Different theoretical models have been proposed, both analysis-oriented models and design-oriented ones. The analysis-oriented models predict the stress-strain behavior of FRP-confined concrete, generally, through an iterative process. Among others, the proposal for circular columns made by Spoelstra and Monti (10), certain approaches for square columns (11) or the generalized model for FRP full and partial confinement arrangements (12) are particularly noteworthy. While the analysis models are usually more accurate, their application tends to be laborious. The design-oriented models provide simple semi-empirical formulations to calculate the increase in strength and deformation of concrete as a function of the FRP confinement pressure and the properties of the unconfined concrete. They are usually based on approaches devised for circular columns, which are then modified by reduction factors related to the two key parameters: the effect of confinement in non-circular sections and the effective strain in the FRP jacket.

The design-oriented models are mostly adopted by the different international design recommendations (13-16). The Lam and Teng model of 2003 (17) is worthy of special mention and its approach was adopted with slight modifications by the ACI guide (13). Likewise, the proposal contained in the fib 90 guide (15) is somewhat similar. Teng et al. proposed two modified versions of this model in 2009 (18) based on new expressions for the ultimate axial strain and concrete strength in which the confinement stiffness and the jacket strain capacity are incorporated separately. This new approach was adopted by the latest revision of the Technical Report TR55 (14).

The most accepted "shape factor" to take into account the effect of the confinement in rectangular sections is based on the "arc effect", taken from the one used in confinement by steel stirrups. However, there are other proposals such as the different patterns of the stress distribution over an FRP confined square section by Lin and Teng (11) or the TR55 guide (14) that assumes conservative values for average confining stress, rather than explicitly defining an effectively confined area.

The effective strain in the FRP at failure is a key parameter. The ultimate strength of the confined concrete is closely related to the value of the reinforcement's failure strain. Numerous experimental studies have shown that its value is somewhat lower than the ultimate strain obtained from standard tensile tests. For rectangular sections the effective ultimate strain can be affected by the corner radius or the side-aspect ratio (8). Empirical values of the strain efficiency factor (ratio of the FRP effective strain to the ultimate tensile strain in uniaxial tension) are enormously divergent in the literature and there is no consensus in the design guidelines.

The work submitted belongs to the research project BIA 2016-80310-P, funded by AEI (Research State Agency of Spanish Ministry of Science and Innovation) and FEDER (European Regional Development Fund). The project aims to contribute to the research on the behavior of FRP confined reinforced concrete columns with square and rectangular cross-sections. To accomplish this, a theoretical and experimental study on the effect of confinement in intermediate-size columns with rectangular section has been carried out. The efficiency reduction due to the aspect ratio of the section has been investigated, along with the effective strain of the FRP jacket.

The study's scope is limited to non-slender plain concrete columns strengthened with fully wrapping of carbon FRP to provide passive confinement. The fibers are applied orthogonally to the axis member with a proper overlap length following the indication of the FRP suppliers. It is valid solely for concrete columns subjected to axial compression loads (non-bending). The unconfined compressive strength of the concrete is not higher than $50 \mathrm{~N} / \mathrm{mm}^{2}$ and the ultimate confined concrete axial strain must be limited to 0.01 , following the recommendations of the $\mathrm{ACI}$ and TR55 guides. 


\section{CONCRETE COMPRESSIVE STRENGTH ACCORDING TO FOUR INTERNATIONAL GUIDES}

The approach of four international guides to predict the strength gain obtained in rectangular section concrete columns has been reviewed. These are namely: Technical Report ACI-440.2R-17 (13), TR55 (14), fib bulletin 90 (15) and CNR-DT200_R1 (16).

\subsection{FRP jacket confinement}

The improvement of concrete strength in the retrofitted column depends on the confinement that the FRP jacket can attain. The confinement is more efficient in circular cross-section members, where the FRP confining pressure $\left(f_{1}\right)$ can be considered uniform over the entire perimeter (Figure 1).

The confining pressure exerted by the FRP jacket $\left(f_{1}\right)$ can be evaluated using an equilibrium analysis similar to that employed to obtain the circumferential stresses in thin wall cylinders, Equation [1]. The FRP materials feature an elastic lineal behavior up to failure. The confining pressure can be expressed as a function of the modulus of elasticity $\left(\mathrm{E}_{\mathrm{f}}\right)$, total thickness $(\mathrm{t})$ and tensile strain of the FRP jacket, as well as the diameter (D) of the concrete column. Experimental studies have shown that the ultimate hoop rupture strain of the FRP (called effective strain in the FRP at failure) is lower than the ultimate tensile strain. The maximum lateral confinement $\left(f_{1}\right)$ occurs for the FRP effective strain $\left(\varepsilon_{\mathrm{fe}}\right)$, Equation [2].

$$
\begin{aligned}
& 2 \sigma_{\mathrm{f}} \mathrm{t}=\mathrm{D} \mathrm{f}_{\mathrm{l}} \\
& \mathrm{f}_{\mathrm{l}}=\frac{2 \mathrm{E}_{\mathrm{f}} \mathrm{t} \varepsilon_{\mathrm{fe}}}{\mathrm{D}}
\end{aligned}
$$

For rectangular sections, the FRP confinement is non-uniform and is most concentrated at the corners. Moreover, the FRP effective strain is lower than the strain achieved in circular columns. The models, mostly based on approaches for circular sections, incorporate factors that take these circumstances into account. It should be noted that the confined concrete stress over a rectangular section is uneven due to the non-uniformity of the FRP confinement. The concrete

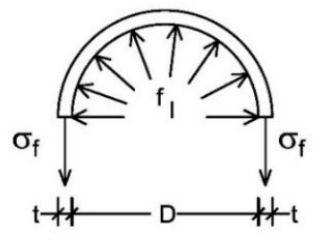

FRP jacket

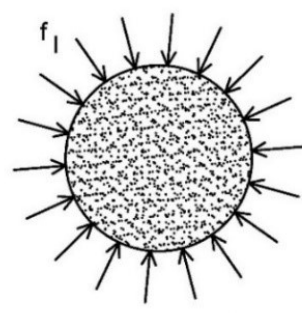

Concrete column
Figure 1. Confinement of circular cross-section. strength is commonly accepted to be the average axial stress calculated as the axial load divided by the cross-sectional area for plain concrete columns.

\subsection{Guides' strength equations}

The Table 1 outlines the equations to calculate the strength enhancement ratio $\left(f_{c c} / f_{c}\right)$ in circular and non-circular cross-sections columns due to the FRP confinement in line with the four international guides (13-16). This formulation is dedicated to continuous FRP wrapping and fibers installed transversally to the longitudinal axis of the strengthened member. The equations are expressed using a common nomenclature to facilitate comparison. The partial safety factors of the materials considered by each guide must be added.

The Table 1 details the limitations contained in the guide for which the proposed equations are valid, such as the maximum value of the aspect ratio of the section $(\mathrm{b} / \mathrm{h})$ or the unconfined concrete strength (f). Furthermore, each guide proposes a minimum value of the confinement ratio $\left(f_{1} / f_{c}\right)$ from which the FRP confinement would be effective. This means the strengthened columns would display bilinear stressstrain curves with a second ascending branch or, at least, that certain strength gain could be expected. For rectangular sections with an aspect ratio higher than 2 (ACI, fib and CNR), or even 1.5 (TR55), the effectiveness of the reinforcement is questioned. The reduction factors for rectangular section used by the guidelines are given in Table 2 .

The following nomenclature has been used in the tables:

- Parameters related to the cross-section: whereby " $\mathrm{D}$ " is the diameter of circular section (for non-circular sections, $\mathrm{D}$ is the equivalent diameter); "b" is the width of rectangular section; " $h$ " is the larger side of rectangular section; " $R$ " is the corner radius of rectangular section; " $A$ " " is the gross area of the concrete section, " $A$ " is the effectively confined concrete area and " $\rho_{g}$ " is the longitudinal steel reinforcement ratio.

- Parameters related to the FRP material: whereby " $\mathrm{E}_{\mathrm{f}}$ " is the tensile modulus of the fiber; " $\mathrm{t}$ " is the total fiber thickness; " $t$ " is the one ply fiber thickness; " $n$ " is the number of FRP layers; " $\varepsilon_{\mathrm{fu}}$ " is the FRP ultimate strain, " $\varepsilon_{\mathrm{fe}}$ " is the effective strain in the FRP at failure, " $\mathrm{f}_{1}$ " is the confinement pressure exerted by the FRP jacket; " $f_{1, \text { eff }}$ " is the effective confinement pressure by CNR and " $\rho_{\mathrm{f}}$ " is the volumetric ratio of FRP reinforcement.

- Parameters related to the concrete: whereby " $\mathrm{f}$ " is the unconfined concrete axil compressive strength (for TR55, $\mathrm{f}_{\mathrm{c}}=0.85 \mathrm{f}_{\mathrm{ck}}$, with $\mathrm{f}_{\mathrm{ck}}$ equal to the characteristic concrete strength); "f $\mathrm{cc}$ " is the confined concrete axial compressive strength; " $\mathrm{f} / \mathrm{f}$ " " is the strength enhancement ratio and " $\varepsilon_{\mathrm{c} 2}$ " is the axial 
strain of the unconfined concrete at the peak stress (usually, equal to $0.2 \%$ for $\mathrm{f}_{\mathrm{c}} \leq 50 \mathrm{~N} / \mathrm{mm}^{2}$ ).

- Reduction factors: whereby " $\psi_{\mathrm{f}}$ " is an additional reduction coefficient contained in the ACI guide; " $k$ " is the FRP strain efficiency factor; " $k$ " is the shape reduction factor considered in the ACI guide; " $\rho_{\mathrm{k}}$ " and " $\rho_{\varepsilon}$ " are the confinement and strain ratio of TR55 guide, " $\alpha_{n}$ " is a shape coefficient used by fib 90; " $\mathrm{k}$ " is the effectiveness factor for FRP confined rectangular columns; " $\mathrm{k}_{\mathrm{H}}$ " is the shape reduction factor for CNR guide and " $\eta$ " is an environmental factor contained in the CNR guide.

\subsection{Analysis of the strength predictions}

For rectangular cross-sections, the confinement efficiency decreases as the aspect ratio of the section $(\mathrm{b} / \mathrm{h})$ increases. It is also influenced by the corner radius of the rectangular section $\left(R_{c}\right)$, columns with a smaller radius appear to display a lower FRP strain efficiency factor $\left(\varepsilon_{\mathrm{fe}} / \varepsilon_{\mathrm{fu}}\right)$. In addition, the confinement efficiency depends on the unconfined concrete strength $\left(f_{c}\right)$, the effect of FRP jacket confinement is limited in high strength concrete. The guides assume all these known circumstances, although their proposals diverge, among others, on two key issues: the effect of confinement in non-circular sections and the FRP effective strain.

For the following analysis, the predictions by using the guides' strength equations are calculated for sections with the same gross concrete area $\left(\mathrm{A}_{\mathrm{c}}\right)$ and different cross-section shapes (circular, square and rectangular with $\mathrm{b} / \mathrm{h}=1.5$ and 2 ). The considered gross concrete area $\left(A_{c}\right)$ is equal to $90000 \mathrm{~mm}^{2}$ and the FRP jacket has $\mathrm{t}=0.39 \mathrm{~mm}, \mathrm{E}_{\mathrm{f}}=230000 \mathrm{~N} / \mathrm{mm}^{2}$ and

TABLE 1. Guide's formulations for assessment of the strength enhancement ratio.

\begin{tabular}{|c|c|c|c|}
\hline Guide & Effective confinement pressure & Strength enhancement ratio & Limitations \\
\hline ACI-440.2R-17 & $\begin{array}{l}\mathrm{f}_{\mathrm{l}}=\frac{2 \mathrm{E}_{\mathrm{f}} \mathrm{tk}_{\varepsilon} \varepsilon_{\mathrm{fu}}}{\mathrm{D}} \\
\text { Non-circular: } \mathrm{D}=\sqrt{\mathrm{b}^{2}+\mathrm{h}^{2}}\end{array}$ & $\begin{array}{l}\frac{f_{c c}}{f_{c}}=1+\psi_{f} 3.3 k_{a} \frac{f_{l}}{f_{c}} \\
\left(\Psi_{f}=0.95\right)\end{array}$ & $\begin{array}{c}\frac{\mathrm{f}_{\mathrm{l}}}{\mathrm{f}_{\mathrm{c}}} \geq 0.08 \\
\mathrm{~b}, \mathrm{~h} \leq 900 \mathrm{~mm} \\
\left(\frac{\mathrm{h}}{\mathrm{b}}\right) \leq 2 \\
\mathrm{f}_{\mathrm{c}} \leq 70 \mathrm{~N} / \mathrm{mm}^{2}\end{array}$ \\
\hline TR55 & $\begin{array}{ll}\text { Circular: } & \rho_{\mathrm{k}}=\frac{2 \mathrm{E}_{\mathrm{f}} t}{\left(\frac{\mathrm{f}_{\mathrm{c}}}{\varepsilon_{\mathrm{c} 2}}\right) \mathrm{D}} \\
\text { Non-circular: } & \rho_{\mathrm{k}}=\frac{\mathrm{E}_{\mathrm{f}} t}{\left(\frac{\mathrm{f}_{\mathrm{c}}}{\varepsilon_{\mathrm{c} 2}}\right) \mathrm{R}_{\mathrm{c}}} \\
\text { Both: } \quad \rho_{\varepsilon} & =\frac{\mathrm{k}_{\varepsilon} \varepsilon_{\mathrm{fu}}}{\varepsilon_{\mathrm{c} 2}} ; \\
& \mathrm{f}_{\mathrm{c}}=0.85 \mathrm{f}_{\mathrm{ck}}\end{array}$ & $\frac{\mathrm{f}_{\mathrm{cc}}}{\mathrm{f}_{\mathrm{c}}}=1+5.25\left(\mathrm{k}_{\mathrm{e}} \rho_{\mathrm{k}}-0.01\right) \rho_{\varepsilon}$ & $\begin{array}{c}\rho_{\mathrm{k}} \geq \frac{0.01}{\mathrm{k}_{\mathrm{e}}} \\
\mathrm{R}_{\mathrm{c}} \geq 20 \mathrm{~mm} \\
\left(\frac{\mathrm{h}}{\mathrm{b}}\right) \leq 1.5\end{array}$ \\
\hline fib 90 & $\begin{aligned} \mathrm{f}_{\mathrm{l}} & =\frac{2 \mathrm{E}_{\mathrm{f}} \mathrm{tk}_{\varepsilon} \varepsilon_{\mathrm{fu}}}{\mathrm{D}} \\
\text { for } \mathrm{n} & \geq 4 \mathrm{t}=\mathrm{n}^{0.85} \mathrm{t}_{\mathrm{f}} \\
\text { Non-circular: } \mathrm{D} & =\frac{2 \mathrm{~b} * \mathrm{~h}}{\mathrm{~b}+\mathrm{h}}\end{aligned}$ & $\begin{array}{l}\text { Circular: } \frac{\mathrm{f}_{\mathrm{cc}}}{\mathrm{f}_{\mathrm{c}}}=1+3.3 \frac{\mathrm{f}_{\mathrm{l}}}{\mathrm{f}_{\mathrm{c}}} \\
\text { Non circular: } \\
\quad \frac{\mathrm{f}_{\mathrm{cc}}}{\mathrm{f}_{\mathrm{c}}}=1+3.3 \propto_{\mathrm{n}}\left(\frac{\mathrm{b}}{\mathrm{h}}\right)^{2} \frac{\mathrm{f}_{\mathrm{l}}}{\mathrm{f}_{\mathrm{c}}}\end{array}$ & $\begin{array}{c}\frac{\mathrm{f}_{\mathrm{l}}}{\mathrm{f}_{\mathrm{c}}} \geq 0.07 \\
\propto_{\mathrm{n}}\left(\frac{\mathrm{b}}{\mathrm{h}}\right)^{2} \frac{\mathrm{f}_{\mathrm{l}}}{\mathrm{f}_{\mathrm{c}}} \geq 0.07 \\
\left(\frac{\mathrm{h}}{\mathrm{b}}\right) \leq 2\end{array}$ \\
\hline CNR-DT 200_R1 & $\begin{array}{l}\mathrm{f}_{\mathrm{l}, \mathrm{eff}}=\mathrm{k}_{\mathrm{H}} \frac{1}{2} \rho_{\mathrm{f}} \mathrm{E}_{\mathrm{f}} \varepsilon_{\mathrm{fe}} \\
\text { Circular: } \rho_{\mathrm{f}}=\frac{4 \mathrm{t}}{\mathrm{D}} \\
\text { Non-circular: } \rho_{\mathrm{f}}=\frac{2 \mathrm{t}(\mathrm{b}+\mathrm{h})}{\mathrm{bh}}\end{array}$ & $\frac{\mathrm{f}_{\mathrm{cc}}}{\mathrm{f}_{\mathrm{c}}}=1+2.6\left(\frac{\mathrm{f}_{\mathrm{l}} \text { eff }}{\mathrm{f}_{\mathrm{c}}}\right)^{2 / 3}$ & $\begin{array}{c}\frac{\mathrm{f}_{\mathrm{l}, \mathrm{eff}}}{\mathrm{f}_{\mathrm{c}}} \geq 0.05 \\
\left(\frac{\mathrm{h}}{\mathrm{b}}\right) \leq 2 \\
\mathrm{~b}, \mathrm{~h} \leq 900 \mathrm{~mm} \\
\mathrm{R}_{\mathrm{c}} \geq 20 \mathrm{~mm}\end{array}$ \\
\hline
\end{tabular}


TABLE 2. Guide's factors.

\begin{tabular}{|c|c|c|}
\hline Guide & Strain efficiency factor & Shape factor \\
\hline ACI-440.2R-17 & $\mathrm{k}_{\varepsilon}=0.55$ & $\begin{array}{l}\text { Circular: } \mathrm{k}_{\mathrm{a}}=1 \\
\text { Non-circular: } \mathrm{k}_{\mathrm{a}}=\frac{\mathrm{A}_{\mathrm{e}}}{\mathrm{A}_{\mathrm{c}}}\left(\frac{\mathrm{b}}{\mathrm{h}}\right)^{2} \\
\frac{\mathrm{A}_{\mathrm{e}}}{\mathrm{A}_{\mathrm{c}}}=\frac{1-\frac{\left[\left(\frac{\mathrm{b}}{\mathrm{h}}\right)\left(\mathrm{h}-2 \mathrm{R}_{\mathrm{c}}\right)^{2}+\left(\frac{\mathrm{h}}{\mathrm{b}}\right)\left(\mathrm{b}-2 \mathrm{R}_{\mathrm{c}}\right)^{2}\right]}{3 \mathrm{~A}_{\mathrm{c}}}-\rho_{\mathrm{g}}}{1-\rho_{\mathrm{g}}}\end{array}$ \\
\hline TR 55 & $\begin{array}{l}\text { Circular: } \mathrm{k}_{\varepsilon}=0.6 \\
\text { Non-circular: } \\
\qquad \mathrm{k}_{\varepsilon}=\left[0.46\left(\frac{2 \mathrm{R}_{\mathrm{c}}}{\mathrm{h}}\right)+0.14\right]\end{array}$ & $\begin{array}{l}\text { Circular: } \mathrm{k}_{\mathrm{e}}=1 \\
\text { Non-circular: } \mathrm{k}_{\mathrm{e}}=\frac{\mathrm{R}_{\mathrm{C}}}{\mathrm{b}}\left(1+\frac{\mathrm{b}}{\mathrm{h}}\right)\end{array}$ \\
\hline$f i b 90$ & $\begin{array}{l}\quad \mathrm{k}_{\varepsilon}=\left\{\begin{array}{c}0.5 \frac{\mathrm{R}_{\mathrm{c}}}{50}\left(2-\frac{\mathrm{R}_{\mathrm{c}}}{50}\right), \mathrm{R}_{\mathrm{c}}<50 \mathrm{~mm} \\
0.5 \quad \mathrm{R}_{\mathrm{c}} \geq 50 \mathrm{~mm}\end{array}\right. \\
\left.\text { (Circular: } \mathrm{R}_{\mathrm{c}}=\mathrm{D} / 2\right)\end{array}$ & $\begin{array}{l}\text { Non-circular: } \propto_{\mathrm{n}}\left(\frac{\mathrm{b}}{\mathrm{h}}\right)^{2} \\
\propto_{\mathrm{n}}=\frac{\mathrm{A}_{\mathrm{e}}}{\mathrm{A}_{\mathrm{c}}}=1-\frac{\left(\mathrm{b}-2 \mathrm{R}_{\mathrm{c}}\right)^{2}+\left(\mathrm{h}-2 \mathrm{R}_{\mathrm{c}}\right)^{2}}{3 \mathrm{~A}_{\mathrm{c}}}\end{array}$ \\
\hline CNR-DT 200_R1 & $\varepsilon_{\mathrm{fe}}=\min \left\{\frac{\eta_{\mathrm{a}} \varepsilon_{\mathrm{fu}}}{\gamma_{\mathrm{f}}} ; 0.004\right\}$ & $\begin{array}{l}\text { Circular: } k_{H}=1 \\
\text { Non-circular: } k_{H}=1-\frac{\left(b-2 R_{c}\right)^{2}+\left(h-2 R_{c}\right)^{2}}{3 A_{c}}\end{array}$ \\
\hline
\end{tabular}

$\varepsilon_{\text {ful }}=0.17 \%$. No partial safety factors have been used with regard to materials.

Figure 2 shows the strength enhancement ratio $\left(\mathrm{f}_{\mathrm{cc}} / \mathrm{f}_{\mathrm{c}}\right)$ versus unconfined concrete strength $\left(\mathrm{f}_{\mathrm{c}}\right)$ for the different section shapes by using the ACI$4402 \mathrm{R}$ and $f i b 90$ guides, considering a corner radius $\left(R_{c}\right)$ of $30 \mathrm{~mm}$ (Figure 2.a) and $50 \mathrm{~mm}$ (Figure 2.b). As expected, the strength enhancement for the square section is lower than for the circular section, this difference being greater for the lower values of the unconfined concrete strength. For rectangular sections with an aspect ratio equal to 1.5 and 2 , the strength improvement is somewhat smaller and

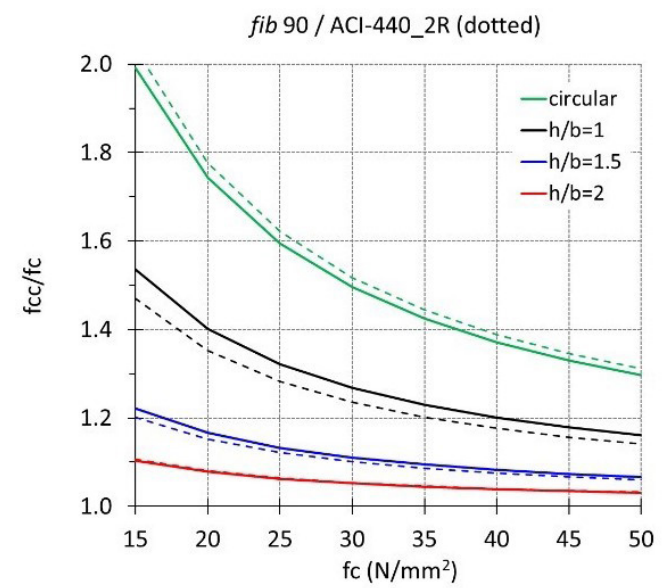

a) requires a low unconfined concrete strength for the reinforcement to be effective. For the larger corner radius $\left(\mathrm{R}_{\mathrm{c}}=50 \mathrm{~mm}\right)$, the prediction of the square section is closer to the circular section. For the square and rectangular sections, the ACI predictions are lower than $f i b$ ones, the difference being greater for the larger corner radius.

Figure 3 shows the strength enhancement ratio $\left(f_{c c} / f_{c}\right)$ versus unconfined concrete strength $\left(f_{c}\right)$ for the square and rectangular $(\mathrm{h} / \mathrm{b}=1.5)$ sections calculated by the four guides. The sections have the equivalent area and the CFRP strengthening above mentioned. The corner radius considered is $30 \mathrm{~mm}$.

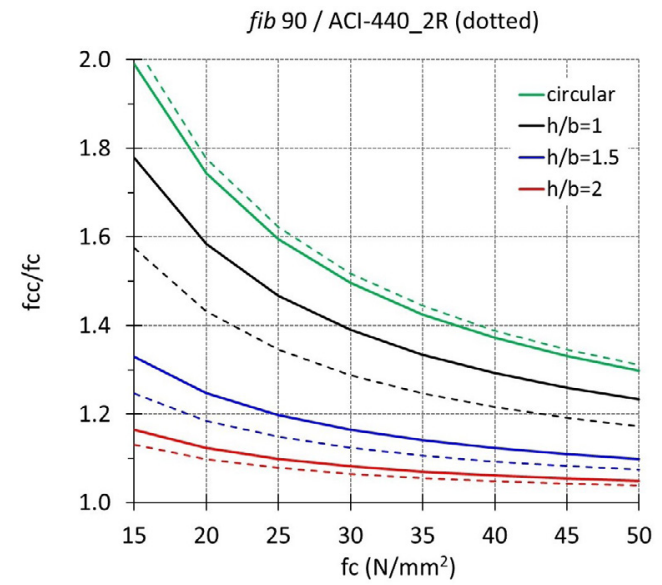

b)

FIGURE 2. Strength enhancement ratio vs unconfined concrete strength for different sections by using the ACI and $f i b$ guidelines: a) $\mathrm{R}_{\mathrm{c}}=30 \mathrm{~mm}$, b) $\mathrm{R}_{\mathrm{c}}=50 \mathrm{~mm}\left(\mathrm{~A}_{\mathrm{c}}=90000 \mathrm{~mm}^{2}, \mathrm{t}=0.39 \mathrm{~mm}, \mathrm{E}_{\mathrm{f}}=230000 \mathrm{~N} / \mathrm{mm}^{2}, \varepsilon_{\mathrm{fu}}=0.17 \%\right)$. 


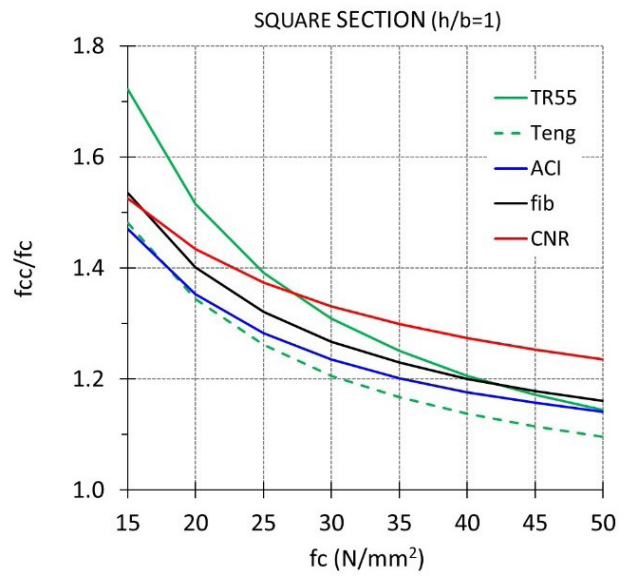

a)

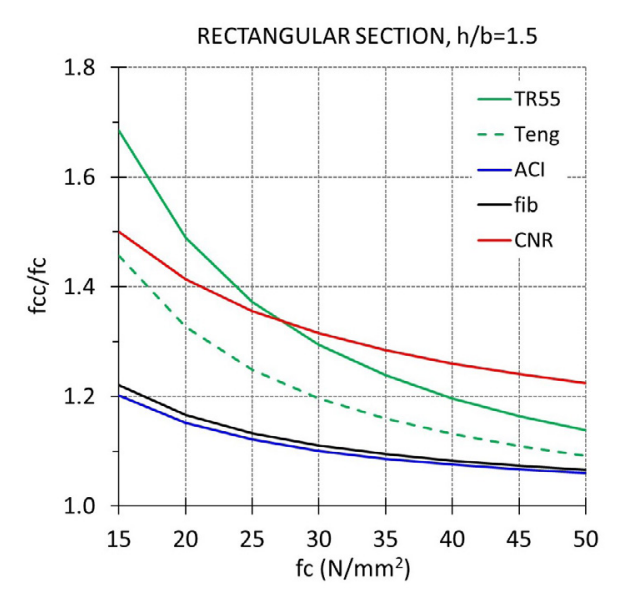

b)

FIGURE 3. Strength enhancement ratio vs unconfined concrete strength for square and rectangular sections $(\mathrm{h} / \mathrm{b}=1.5)$ by four guidelines $\left(\mathrm{A}_{\mathrm{c}}=90000 \mathrm{~mm}^{2}, \mathrm{t}=0.39 \mathrm{~mm}, \mathrm{E}_{\mathrm{f}}=230000 \mathrm{~N} / \mathrm{mm}^{2}, \varepsilon_{\mathrm{fu}}=0.17 \%, \mathrm{R}_{\mathrm{c}}=30 \mathrm{~mm}\right)$.

For square sections, the prediction is more consistent. For rectangular sections with an aspect ratio equal to 1.5 , the $\mathrm{ACI}$ and $f i b$ guidelines are more conservative than the others. The strength equation of TR55 guide comes from the model of Teng et al. (18) but this guide uses a numerical coefficient of 5.5 instead of the original value of 3.5. In the graph the strength prediction of the model (18) is plotted in dot line, which is more in line with the rest of the guides, especially for square sections.

The equivalent diameter for rectangular cross-section considered by the guides differs. ACI adheres to Lam and Teng's proposal (17) and uses the diameter of the equivalent circle that circumscribes the rectangular section. The $f i b$ guide uses the diagonal of a circular section that has the same FRP volumetric ratio as the original rectangular section (CNR follows the same approach). Both parameters are related to the shape of the section and the ratio of the ACI equivalent diameter to the $f i b$ one is constant for each aspect ratio $(\mathrm{b} / \mathrm{h})$. The ACI equivalent diameter is higher and this has a bearing on ACI strength predictions being lower.

\subsection{Shape factor}

Certain international guides use a shape factor (Table 2) calculated from the ratio of the effective confinement area and the gross area of the column cross-section $\left(\mathrm{A}_{\mathrm{e}} / \mathrm{A}_{\mathrm{c}}\right)$. The $\mathrm{CNR}$ and $f i b 90$ guides follow the same approach, assuming that only the concrete within the area cordoned off using four parabolas that intersect the edges at $45^{\circ}$ is effectively confined, Figure 4.a. The ACI guide uses a modified version, in which the initial slopes of the parabolas are the same of the adjacent diagonal lines, Figure 4.b. This modification prevents the ratio $\left(\mathrm{A}_{\mathrm{e}} / \mathrm{A}_{\mathrm{c}}\right)$ becoming negative if the aspect ratio $(\mathrm{h} / \mathrm{b})$ is greater than 2.6 and the corners are not rounded. The coefficient " $\mathrm{e}_{\mathrm{e}}$ " proposed by TR55 guide is not related to this approach, this code assumes a simpler average

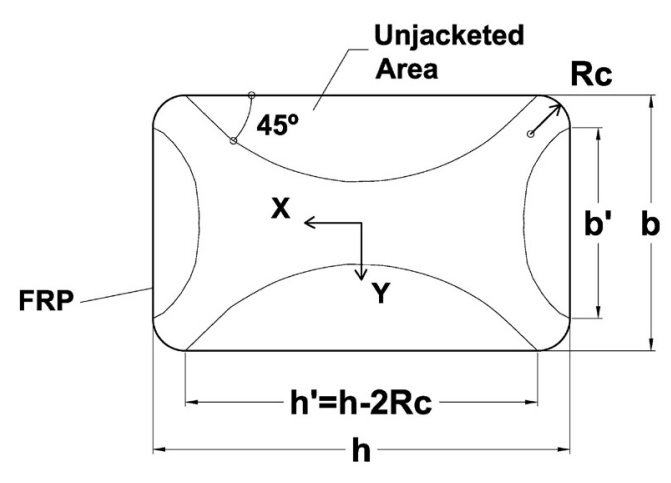

a)

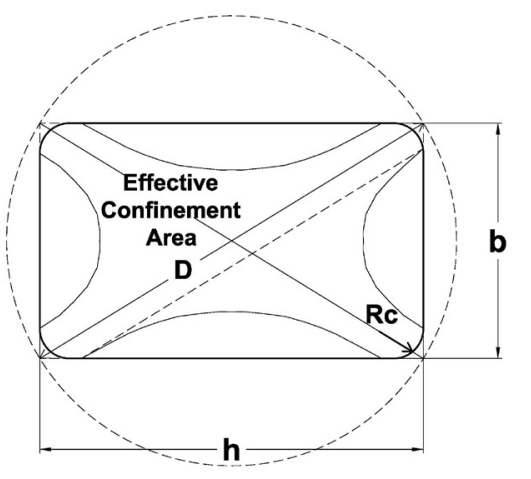

b)

FiguRE 4. Effective confinement area according to: a) CNR-DT 200_R1, b) ACI-440.2R-17. 


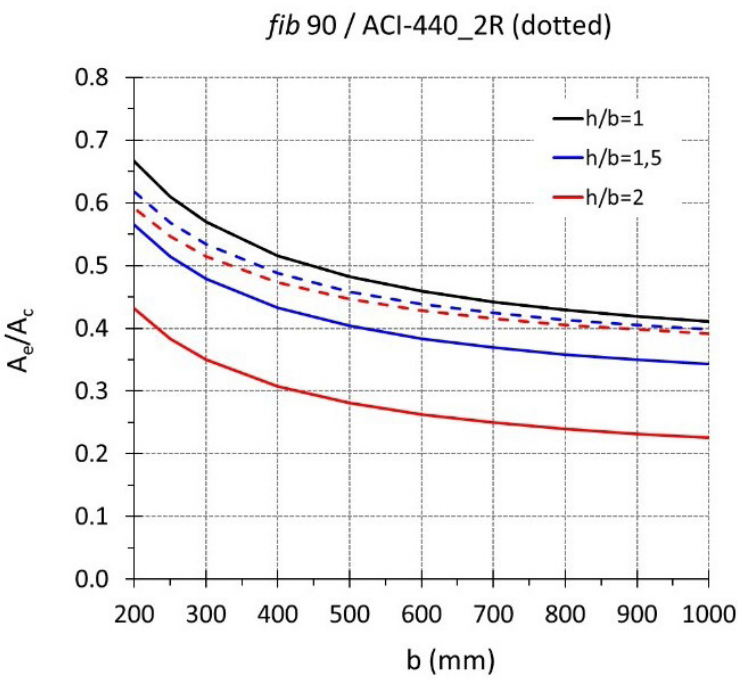

a)

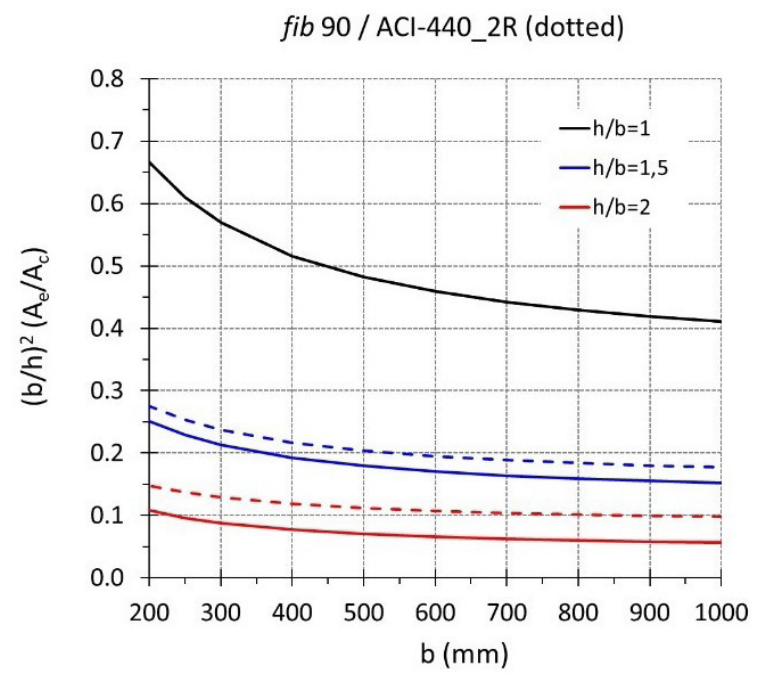

b)

FIgURE 5. Shape reduction factors for different rectangular sections $\left(\mathrm{R}_{\mathrm{c}}=30 \mathrm{~mm}\right)$ by using the ACI and fib guidelines: a) Ratio of effectively confined concrete area: $\left.\left(\mathrm{A}_{\mathrm{e}} / \mathrm{A}_{\mathrm{c}}\right), \mathrm{b}\right)$ Shape factor: $(\mathrm{b} / \mathrm{h})^{2}\left(\mathrm{~A}_{\mathrm{e}} / \mathrm{A}_{\mathrm{c}}\right)$.

confining stress approach, rather than explicitly defining an effectively confined area.

The expressions match in square sections without steel longitudinal reinforcement. However, for rectangular ones with an aspect ratio equal to 1.5 and 2 , the values of $\left(\mathrm{A}_{\mathrm{e}} / \mathrm{A}_{\mathrm{c}}\right)$ calculated with $f i b$ (and $\mathrm{CNR}$ ) guidelines are more conservative, Figure 5.a. However, the shape factors of $f i b$ and ACI guides are obtained by multiplying the ratio $\left(\mathrm{A}_{\mathrm{e}} / \mathrm{A}_{\mathrm{c}}\right)$ by the square of the aspect ratio $(\mathrm{b} / \mathrm{h})$. As can be seen in Figure 5.b, these shape factors are ultimately similar, with the $f i b$ shape factor being slightly more conservative. For rectangular sections, the action of incorporating the factor $(\mathrm{b} / \mathrm{h})^{2}$, minimizes the incidence of the different calculation of $\left(\mathrm{A}_{\mathrm{e}} / \mathrm{A}_{\mathrm{c}}\right)$.

In collaboration with the Technological Institute of Aragon (ITAINNOVA), a numerical model based on the finite element method (FEM) has been carried out via Abaqus software. Circular and rectangular columns were modelled to study the inci- dence of different variables such as the amount of FRP reinforcement or the corner radius. The FEM model allows us to study the non-uniform confinement in the rectangular section. Figure 6 shows the stress distribution in circular and rectangular cross-section. The stress distribution for rectangular turns out to be similar to that proposed by the guides. However, the graph shows confinement stresses, although lower, outside the effectively confined area, not considered by the guides for reasons of simplicity (11).

\subsection{Strain efficiency factor}

The FRP effective strain $\left(\varepsilon_{\mathrm{fe}}\right)$ achieved in axial load tests are much lower than the ultimate tensile strain obtained using the tensile coupon test method $\left(\varepsilon_{\mathrm{fu}}\right)$. There are a number of possible reasons for this, such as multiaxial stress-state, stress concentrations due
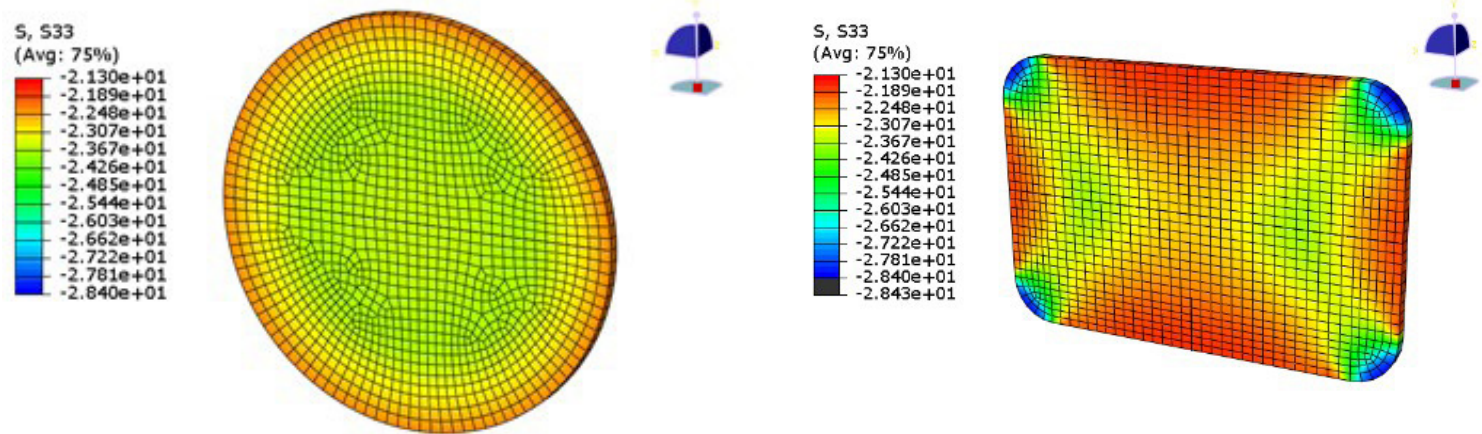

FIGURE 6. Stress distribution from the FEM Model: a) circular section ( $D=350 \mathrm{~mm}$ and two CFRP layers), b) rectangular section $\left(375 \times 250 \mathrm{~mm}^{2}, \mathrm{R}_{\mathrm{c}}=40 \mathrm{~mm}\right.$ and three CFRP layers $)$. 
to concrete failure, or a curved shape of the jacket, especially at corners with a low radius for square or rectangular columns.

There is no consensus on the design guidelines regarding the strain efficiency factor value $\left(\varepsilon_{\mathrm{fe}} / \varepsilon_{\mathrm{fu}}\right)$. ACI-440.2R-17 proposes a factor equal to 0.55 , for both circular and rectangular sections, based on the average value reported by several researchers. fib Bulletin 90 proposes a strain efficiency factor equal to 0.5 for circular sections, and lower values, depending on the radius of the corners, for rectangular columns. TR55 also recommends lower values for the strain factor in rectangular sections, depending on the corner radius and the longest side of the section. CNR-DT200_R1 does not distinguish between circular and rectangular sections and, in practice, limits the FRP effective strain to 0.004 in order to avoid excessive cracking on the concrete.

\subsection{Ultimate axial strain of the confined concrete}

The guides propose another set of equations to calculate the ultimate concrete axial strain for the FRP strengthened column. The experimental studies have shown it is possible to obtain significant increases in strain capacity. However, for practical applications, high values of concrete axial strains should be avoided, since, even if the FRP jacket is far from failure, the internal concrete will be highly cracked and the column would not be able to withstand transversal forces. Certain design guides (ACI, TR55) recommend considering a maximum value of the ultimate concrete strain of 0.01 .

\section{CIRCULAR CONCRETE SPECIMENS STRENGTHENED WITH CFRP JACKETS}

The research project includes tests, mostly, on square and rectangular concrete specimens strengthened with carbon FRP jackets, Figure 7. Some circu-

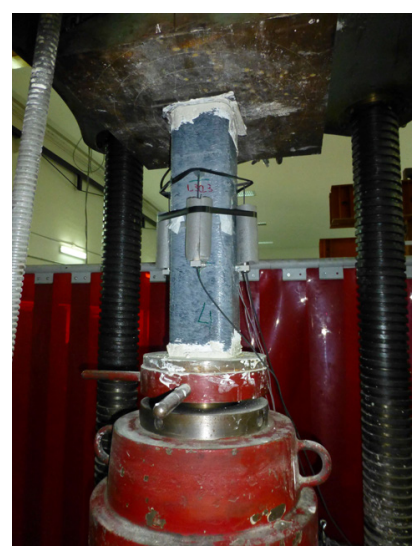

a)

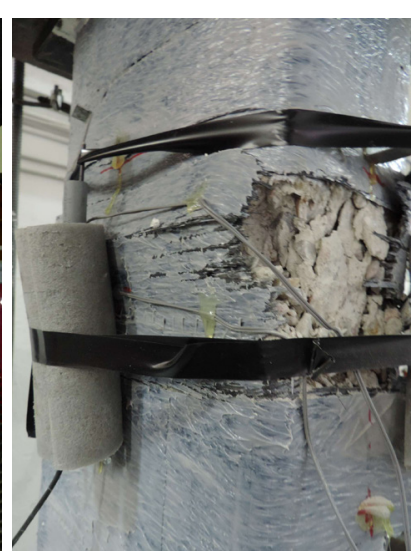

b)

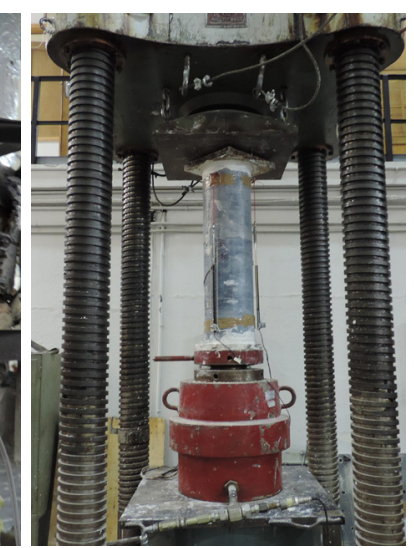

c) lar specimens were also tested; these are detailed in this section.

\subsection{Circular tests of the research project}

Four plain concrete specimens with circular cross-section have been tested under centered compression. They were strengthened applying one ply of unidirectional carbon-fiber reinforced polymer (CFRP) along the full height using the hand lay-up technique.

The CFRP had a nominal fiber thickness of 0.129 $\mathrm{mm}$ per ply and the following mechanical properties: a mean value for ultimate strength of $4161 \mathrm{~N} / \mathrm{mm}^{2}$, a tensile modulus of $236918 \mathrm{~N} / \mathrm{mm}^{2}\left(\mathrm{E}_{\mathrm{f}}\right)$ and a mean value for ultimate strain of $0.01776\left(\varepsilon_{\mathrm{fu}}\right)$. The fibers were placed orthogonally to the axis member. The CFRP overlap length was $100 \mathrm{~mm}$.

Eight electrical strain gauges were glued to the FRP jacket on the mid-height, four arranged axially and the other four, laterally. The axial deformations were also measured with four linear variable-displacement transducers (LVDTs). The load, strains and LVDT displacements were monitored using an electronic data acquisition system. Axial compression tests were conducted using a hydraulic jack.

The Table 3 shows the main tests parameters, such as: the diameter specimen $(\mathrm{D})$; the height $(\mathrm{H})$; the total fiber thickness $(\mathrm{t})$ and the unconfined concrete strength $\left(f_{c}\right)$, obtained from cylinders that were cast as the same time as the specimen. The table also includes the experimental results: the confined concrete strength $\left(\mathrm{f}_{\mathrm{cc}}\right)$ or maximum concrete axial stress at the peak of strain-stress curve; the strength enhancement ratio $\left(\mathrm{f}_{\mathrm{cc}} / \mathrm{f}_{\mathrm{c}}\right)$; the CFRP jacket hoop rupture $\left(\varepsilon_{\mathrm{fe}}\right)$ and the strain efficiency factor $\left(\varepsilon_{\mathrm{fe}} / \varepsilon_{\mathrm{fu}}\right)$.

The CFRP jacket is highly efficient for circular cross-section concrete elements. The strength enhancement ratio $\left(f_{c c} / f_{c}\right)$ with only one CFRP ply has varied from three (for one of the specimens with the smallest diameter) to two. The failure mode of the

FiguRE 7. a) Rectangular test set-up, b) Failure mode of rectangular specimen, c) Circular test set-up, d) Failure mode of circular specimen. 
TABLE 3. Main parameters and test results of circular specimens tested.

\begin{tabular}{ccccccccc}
\hline & $\begin{array}{c}\mathrm{D} \\
{[\mathrm{mm}]}\end{array}$ & $\begin{array}{c}\mathrm{H} \\
{[\mathrm{mm}]}\end{array}$ & $\begin{array}{c}\mathrm{t} \\
{[\mathrm{mm}]}\end{array}$ & $\begin{array}{c}\mathrm{f}_{\mathrm{c}}[\mathrm{N} / \\
\left.\mathrm{mm}^{2}\right]\end{array}$ & $\begin{array}{c}\mathrm{f}_{\mathrm{cc}}[\mathrm{N} / \\
\left.\mathrm{mm}^{2}\right]\end{array}$ & $\begin{array}{c}\mathrm{f}_{\mathrm{cc}} / \mathrm{f}_{\mathrm{c}} \\
\varepsilon_{\mathrm{fe}}\end{array}$ & $\begin{array}{c}\boldsymbol{\varepsilon}_{\mathrm{fe}} / \boldsymbol{\varepsilon}_{\mathrm{fu}} \\
{[\%]}\end{array}$ \\
\hline $1 \mathrm{a}$ & 140 & 500 & 0.129 & 20.40 & 63.05 & 3.09 & 1.25 & 0.70 \\
\hline $\mathrm{1b}$ & 140 & 500 & 0.129 & 20.40 & 56.34 & 2.76 & 1.40 & 0.79 \\
\hline $2 \mathrm{a}$ & 220 & 800 & 0.129 & 20.98 & 45.5 & 2.17 & 1.73 & 0.97 \\
\hline $2 \mathrm{~b}$ & 220 & 800 & 0.129 & 20.98 & 43.7 & 2.08 & 1.35 & 0.76 \\
\hline
\end{tabular}
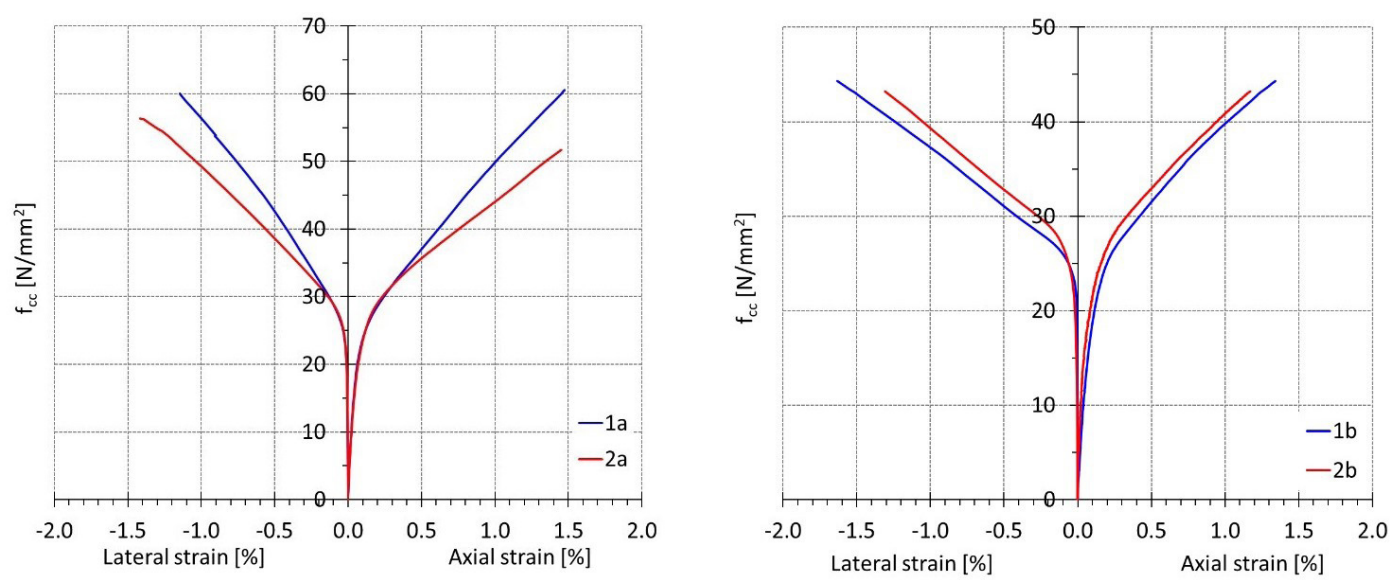

FIGURE 8. Stress-strain curves of specimens with circular cross-section: a) $h=500 \mathrm{~mm}, \mathrm{~b}$ ) $\mathrm{h}=800 \mathrm{~mm}$.

specimens was largely due to the tensile rupture of the CFRP strengthening.

The Figure 8 shows the axial stress vs axial and lateral strain curves, grouped by specimens with the same height. The tests display monotonically ascending curves, typical of "well-confined" concrete.

\subsection{Strain efficiency factor for circular cross section elements strengthened with CFRP jackets}

The ultimate strain of the CFRP jacket in the hoop direction, or FRP effective strain, for each test is displayed in Table 3 . It is the mean value of the measurements from the lateral strain gauges, omitting those glued on the overlap region as these are not representative. The mean value of the strain efficiency factor $\left(\boldsymbol{\varepsilon}_{\mathrm{fe}} / \boldsymbol{\varepsilon}_{\mathrm{fu}}\right)$ for the two specimens measuring $500 \mathrm{~mm}$ in height is 0.75 . For the two specimens measuring $800 \mathrm{~mm}$ in height is 0.87 . The mean strain efficiency factor of the four specimens has resulted of 0.81 .

The results have been compared to others from CFRP strengthened cylindrical specimens that are included in the database compiled by Ozbakkaloglu and Lim (3). To perform this task, intermediate size specimens have been chosen (height from $450 \mathrm{~mm}$ to $762 \mathrm{~mm}$ ), eliminating those with a strain efficiency factor $\left(\varepsilon_{\mathrm{fe}} / \varepsilon_{\mathrm{fu}}\right)$ greater than one. The Table 4 outlines the main parameters and test results of the database tests.
For the database tests containing information on the ultimate CFRP jacket hoop strain, the mean value of the strain efficiency factor is 0.74 . Under laboratory conditions, the FRP jacket in circular specimens tested under perfectly centered axial load can reach extremely high values of lateral strain, still these circumstances may not occur in real applications. For this reason, two tests with an excessive strain efficiency factor (equal or higher than 0.90) have been eliminated. The mean value of the strain efficiency factor of the available circular tests (Tables 3-4 except the two specimens with a strain efficiency factor equal or higher than 0.90 ) results 0.73 .

In this paper, a value for the strain efficiency factor equal to 0.73 is used to ascertain the calculation of compressive strength in CFRP confined concrete columns with circular cross sections.

\subsection{Confined concrete strength in circular cross- section elements strengthened with CFRP jackets}

The results of the available circular tests (Tables 3-4 except the two specimens with a strain efficiency factor equal or higher than 0.90 ) were compared with the theoretical predictions by the four international guides (13-16). There are 39 experimental results, 4 belonging to the research project and 35 to the database studies.

The graphs with the comparison between the experimental results and the theoretical predictions by 
TABLE 4. Tests on circular specimens from database compiled by Ozbakkaloglu and Lim (3).

\begin{tabular}{|c|c|c|c|c|c|c|c|c|c|c|}
\hline & $\begin{array}{c}\mathrm{D} \\
{[\mathrm{mm}]}\end{array}$ & $\begin{array}{c}\mathrm{H} \\
{[\mathrm{mm}]}\end{array}$ & $\begin{array}{c}\mathrm{t} \\
{[\mathrm{mm}]}\end{array}$ & $\begin{array}{c}E_{\mathrm{f}} \\
{\left[\mathrm{N} / \mathrm{mm}^{2}\right]}\end{array}$ & $\begin{array}{c}\varepsilon_{\mathrm{fu}} \\
{[\%]}\end{array}$ & $\mathrm{f}_{\mathrm{c}}\left[\mathrm{N} / \mathrm{mm}^{2}\right]$ & $\mathrm{f}_{\mathrm{cc}}\left[\mathrm{N} / \mathrm{mm}^{2}\right]$ & $\mathrm{f}_{\mathrm{cc}} / \mathrm{f}_{\mathrm{c}}$ & $\begin{array}{c}\varepsilon_{\mathrm{fe}} \\
{[\%]}\end{array}$ & $\boldsymbol{\varepsilon}_{\mathrm{fe}} / \boldsymbol{\varepsilon}_{\mathrm{fu}}$ \\
\hline Carey et al. & 254 & 762 & 1.00 & 72500 & 1.21 & 38.90 & 54.80 & 1.41 & 1.00 & 0.83 \\
\hline Liang et al. & 300 & 600 & 0.50 & 242000 & 1.48 & 24.50 & 58.80 & 2.40 & 0.98 & 0.66 \\
\hline Liang et al. & 300 & 600 & 0.50 & 242000 & 1.48 & 24.50 & 59.40 & 2.42 & 1.33 & 0.90 \\
\hline Liang et al. & 300 & 600 & 0.50 & 242000 & 1.48 & 24.50 & 60.60 & 2.47 & 1.22 & 0.82 \\
\hline Smith et al. & 250 & 500 & 0.26 & 210520 & 1.51 & 35.00 & 50.00 & 1.43 & 0.89 & 0.59 \\
\hline Smith et al. & 250 & 500 & 0.26 & 210520 & 1.51 & 35.00 & 57.00 & 1.63 & 1.22 & 0.81 \\
\hline Smith et al. & 250 & 500 & 0.26 & 210520 & 1.51 & 35.00 & 59.00 & 1.69 & 1.31 & 0.87 \\
\hline Smith et al. & 250 & 500 & 0.26 & 210520 & 1.51 & 35.00 & 56.00 & 1.60 & 1.15 & 0.76 \\
\hline Song et al. & 150 & 450 & 0.13 & 237000 & 1.72 & 22.40 & 45.70 & 2.04 & 1.12 & 0.65 \\
\hline Song et al. & 150 & 450 & 0.26 & 237000 & 1.72 & 22.40 & 65.40 & 2.92 & 1.18 & 0.69 \\
\hline Song et al. & 150 & 450 & 0.39 & 237000 & 1.72 & 22.40 & 85.00 & 3.79 & 1.21 & 0.70 \\
\hline Song et al. & 150 & 450 & 0.13 & 237000 & 1.72 & 40.90 & 57.10 & 1.40 & 1.24 & 0.72 \\
\hline Song et al. & 150 & 450 & 0.26 & 237000 & 1.72 & 40.90 & 78.40 & 1.92 & 1.07 & 0.62 \\
\hline Song et al. & 150 & 450 & 0.39 & 237000 & 1.72 & 40.90 & 100.40 & 2.45 & 1.16 & 0.68 \\
\hline Akogbe et al. & 300 & 600 & 0.50 & 242000 & 1.34 & 24.50 & 58.80 & 2.40 & - & - \\
\hline Akogbe et al. & 300 & 600 & 0.50 & 242000 & 1.34 & 24.50 & 59.40 & 2.42 & - & - \\
\hline Akogbe et al. & 300 & 600 & 0.50 & 242000 & 1.34 & 24.50 & 63.00 & 2.57 & - & - \\
\hline Akogbe et al. & 300 & 600 & 0.50 & 242000 & 1.34 & 24.50 & 60.60 & 2.47 & - & - \\
\hline Hosotani et al. & 200 & 600 & 0.44 & 230000 & 1.51 & 41.70 & 93.00 & 2.23 & - & - \\
\hline Ongpeng & 180 & 500 & 0.13 & 231000 & 1.58 & 27.00 & 37.23 & 1.38 & - & - \\
\hline Ongpeng & 180 & 500 & 0.26 & 231000 & 1.58 & 27.00 & 51.18 & 1.90 & - & - \\
\hline Shehata et al. & 225 & 450 & 0.17 & 235000 & 1.51 & 34.00 & 43.70 & 1.29 & - & - \\
\hline Shehata et al. & 225 & 450 & 0.33 & 235000 & 1.51 & 34.00 & 62.90 & 1.85 & - & - \\
\hline Thériault et al. & 304 & 608 & 0.66 & 230000 & 1.51 & 37.00 & 66.00 & 1.78 & - & - \\
\hline Yan et al. & 305 & 610 & 1.00 & 86900 & 1.40 & 15.00 & 37.80 & 2.52 & - & - \\
\hline Youssef et al. & 406 & 813 & 5.84 & 103840 & 1.20 & 29.40 & 125.80 & 4.28 & - & - \\
\hline Youssef et al. & 406 & 813 & 5.84 & 103840 & 1.20 & 29.40 & 126.39 & 4.30 & - & - \\
\hline Youssef et al. & 406 & 813 & 5.84 & 103840 & 1.20 & 29.40 & 127.01 & 4.32 & - & - \\
\hline Youssef et al. & 406 & 813 & 3.50 & 103840 & 1.20 & 29.40 & 83.05 & 2.82 & - & - \\
\hline Youssef et al. & 406 & 813 & 3.50 & 103840 & 1.20 & 29.40 & 88.68 & 3.02 & - & - \\
\hline Youssef et al. & 406 & 813 & 2.34 & 103840 & 1.20 & 29.40 & 64.78 & 2.20 & - & - \\
\hline Youssef et al. & 406 & 813 & 2.34 & 103840 & 1.20 & 29.40 & 62.09 & 2.11 & - & - \\
\hline Youssef et al. & 406 & 813 & 2.34 & 103840 & 1.20 & 29.40 & 67.47 & 2.29 & - & - \\
\hline Youssef et al. & 406 & 813 & 1.17 & 103840 & 1.20 & 29.40 & 45.95 & 1.56 & - & - \\
\hline Youssef et al. & 406 & 813 & 1.17 & 103840 & 1.20 & 29.40 & 45.78 & 1.56 & - & - \\
\hline
\end{tabular}

each guide are shown in Figure 9, indicating the root mean square error (RMSE) that is only interpreted comparatively. No partial safety factors of materials have been used to obtain the predictions.

The predictions made by using TR55 equations are more in line with the general trend followed by the experimental results. The ACI and fib guides predictions offer reasonable matches, with all theoretical predictions being equal or lower than experimental results. The CNR guide predictions diverged slightly further from the tests results.

Equation [3] displays the general form of the strength equation by the $f i b 90$ and ACI-400_2R guides.

$$
\begin{aligned}
& \frac{\mathrm{f}_{\mathrm{cc}}}{\mathrm{f}_{\mathrm{c}}}=1+\alpha \mathrm{k}_{\mathrm{S}} \mathrm{k}_{\varepsilon} \frac{\mathrm{f}_{\mathrm{lu}}}{\mathrm{f}_{\mathrm{c}}} \\
& \text { with } \mathrm{f}_{\mathrm{lu}}=\frac{2 \mathrm{E}_{\mathrm{f}} \mathrm{t} \varepsilon_{\mathrm{fu}}}{\mathrm{D}}
\end{aligned}
$$


Experimental analysis and design strength models adopted by international guides for FRP-confined concrete columns subjected... $\bullet 11$

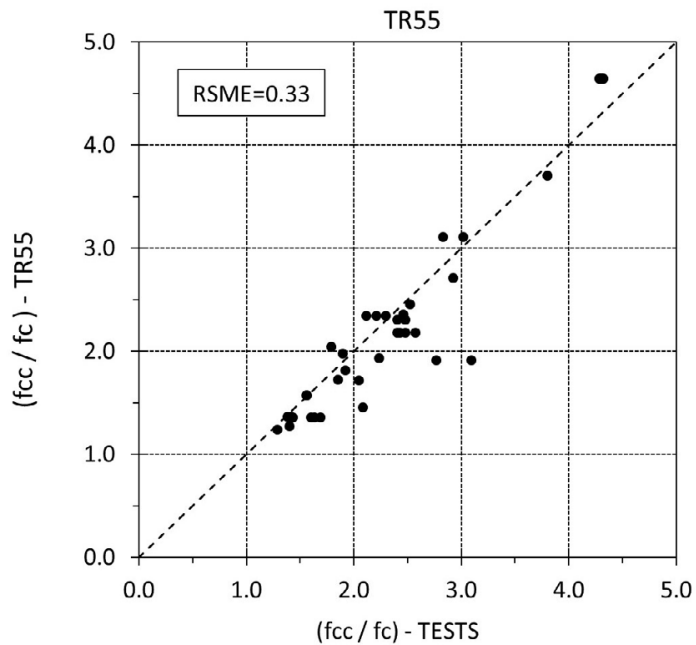

a)

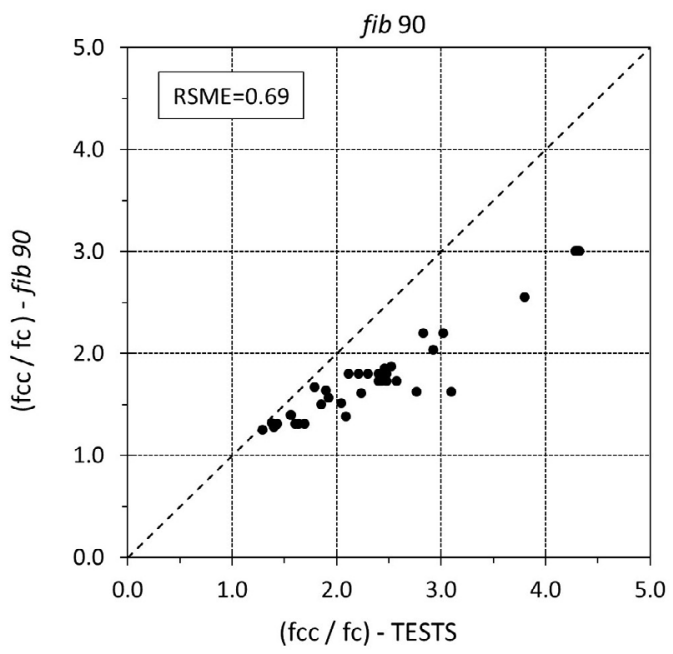

c)

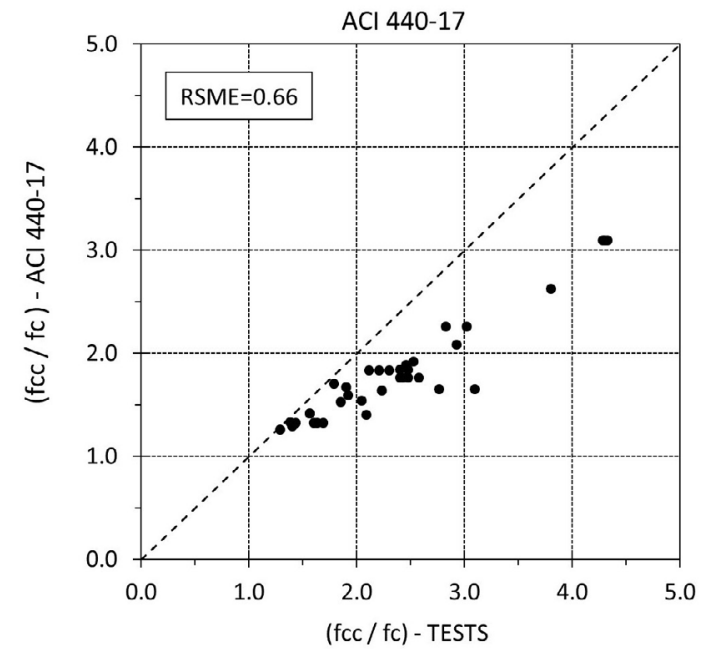

b)

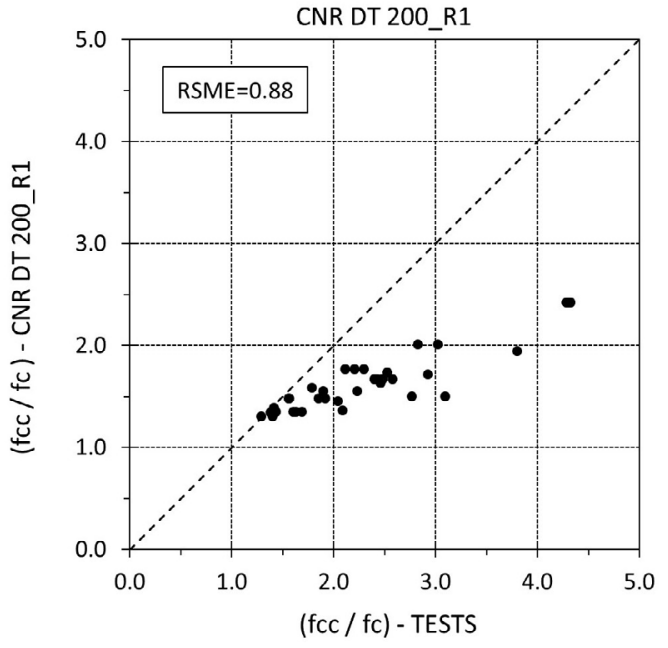

d)

FIGURE 9. Experimental strength enhancement ratio vs predicted values by guidelines.

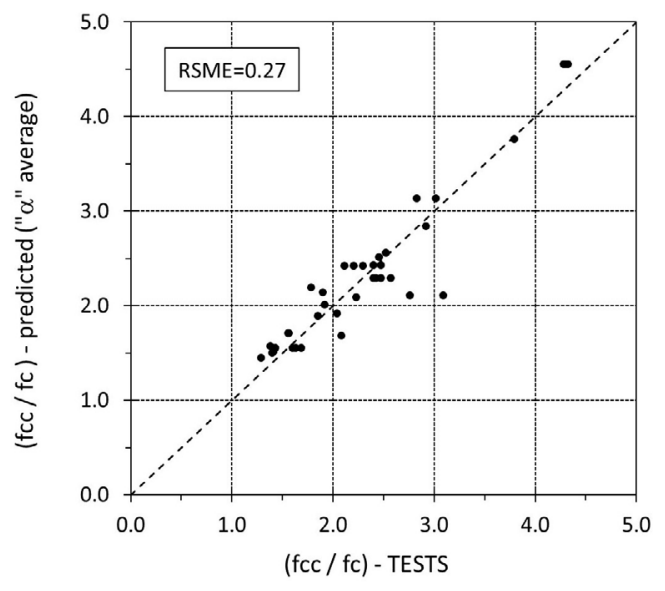

a) $\alpha=4.0$ (average value)

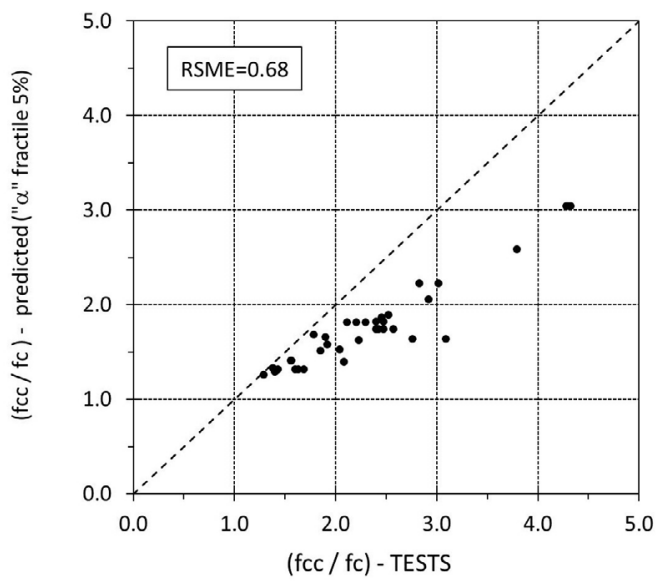

b) $\alpha=2.3$ (fractile $5 \%$ )

FIGURE 10. Experimental strength enhancement ratio vs predicted values with $\mathrm{k}_{\varepsilon}=\boldsymbol{\varepsilon}_{\mathrm{fe}} / \boldsymbol{\varepsilon}_{\mathrm{fu}}=0.73$. 
The value of the numerical coefficient " $\alpha$ " can be obtained by using the strain efficiency factor estimated as 0.73 for the available circular tests. The reduction strain factor $\left(\mathrm{k}_{\varepsilon}\right)$ and the shape factor $\left(\mathrm{k}_{\mathrm{S}}\right)$ would be equal to one (circular section). A mean value of the coefficient " $\alpha$ " equal to 4.0 and a characteristic value of 2.3 ( $5 \%$ fractile) has thus been obtained. Figure 10 shows the graphs with the comparison between the experimental results and the predictions by means of the Equation [3] and the above values of " $\alpha$ ".

The proposed strain efficiency factor for circular columns (equal to 0.73 ) with the characteristic value of the coefficient " $\alpha$ " (equal to 2.3) unearths a similar accuracy to $f i b$ predictions. Using the mean value of the coefficient " $\alpha$ " (equal to 4 ), the adjustment is slightly better than in the TR55 guide.

\section{RECTANGULAR CONCRETE SPECIMENS STRENGTHENED WITH CFRP JACKETS}

\subsection{Square and rectangular tests of the research project}

Project BIA 2016-80310 includes a large experimental campaign on intermediate-size plain concrete specimens with rectangular cross-section tested under centered compression. The specimens were formed by low and medium strength concrete (unconfined compressive strength of 20 to $35 \mathrm{~N} / \mathrm{mm}^{2}$ ) measuring $600 \mathrm{~mm}$ in height. The side-aspect ratio $(\mathrm{b} / \mathrm{h})$ of the cross-section varied between $1,1.5$ and 2 . The radius of curvature $\left(R_{c}\right)$ of the corners was 20, 25 and $30 \mathrm{~mm}$. Different number of plies of unidirectional carbon-fiber reinforced polymer (CFRP) were applied along the entire height using the hand lay-up technique. The CFRP material used was the same described for the circular test of the above section $\left(\mathrm{t}=0.129 \mathrm{~mm}\right.$ per ply, $\mathrm{E}_{\mathrm{f}}=236918 \mathrm{~N} / \mathrm{mm}^{2}$ and $\varepsilon_{\text {fu }}=0.01776$ ). The fibers were orthogonal to the axis member with an overlap length of $100 \mathrm{~mm}$.

In order to study the mechanical behavior, electrical strain gauges were glued to the FRP jacket in the middle of each side at the mid height point. Four were arranged axially and two, laterally. The axial deformations were measured using four linear variable-displacement transducers (LVDTs). This information was monitored using an electronic data acquisition system, while axial compression tests were conducted using a hydraulic jack.

From the experimental program, twenty-five specimens have been chosen (those that exhibited a concrete compressive strength enhancement greater than 1.05). Table 5 shows the main test parameters: width (b); longer side $(\mathrm{h})$; corner radius $\left(\mathrm{R}_{\mathrm{c}}\right)$; the total fiber thickness $(t)$ and the unconfined concrete strength $\left(f_{c}\right)$, obtained from cylinders that were cast as the same time as the specimen. The table also includes the results for: the confined concrete strength $\left(f_{c c}\right)$ or max- imum concrete axial stress at the peak of the strainstress curve; the strength enhancement ratio ( $\mathrm{f} / \mathrm{f}$ ); the CFRP jacket hoop strain at rupture $\left(\varepsilon_{\mathrm{fe}}\right)$ and the strain efficiency factor $\left(\varepsilon_{\mathrm{fe}} / \varepsilon_{\mathrm{fu}}\right)$.

The specimens failed mainly due to tensile rupture of the CFRP strengthening near to the corner.

For illustrative purposes only, the graph in Figure 11 shows the compressive strength enhancement ratio obtained for three strengthened specimens compared to a non-strengthened one (reference). Specifically, one square cross-section specimen (1_2_25a) and one rectangular with side-aspect ratio $(\bar{b} / \mathrm{h})$ equal to 1.5 (1.5 2 25a), both strengthened with the addition of two $\bar{C} F \bar{R} P$ layers. They are compared to a rectangular version with side-aspect ratio $(\mathrm{b} / \mathrm{h})$ equal to 2 (2 3 25) strengthened with three CFRP layers. For all side-aspect rates, the strain capacity improved owing to the CFRP jacket action. In this case, only the specimens with side-aspect ratio other than two exhibited monotonically ascending curves, typical of "well-confined" concrete. As it is known, the confinement efficiency decreases as the aspect ratio of the section increases.

\subsection{Strain efficiency factor for rectangular cross- section elements strengthened with CFRP jackets}

The ultimate strain of the CFRP jacket in the hoop direction, or FRP effective strain, for each test is obtained from the mean value of four sides measured and is collected in the Table 5. For these rectangular tests, the mean value of the strain efficiency factor $\left(\varepsilon_{\mathrm{fe}} / \varepsilon_{\mathrm{fu}}\right)$ of the specimens with side-aspect ratio $(\mathrm{b} / \mathrm{h})$ equal to 1 is 0.65 ; for those with $\mathrm{b} / \mathrm{h}=1.5$ this is 0.52 and for those with $\mathrm{b} / \mathrm{h}=2$ this is 0.39 . The results have been compared to others from CFRP strengthened plain concrete specimens with square and rectangular sections that are included in the database compiled by Pham and Hadi (7). For this task, intermediate size specimens have been chosen (height from $450 \mathrm{~mm}$ to $915 \mathrm{~mm}$ ), eliminating those with concrete compressive strength enhancement equal or lower than 1.05 or corner radius excessive small (minimum $\mathrm{R}_{\mathrm{c}}=20 \mathrm{~mm}$ ).

The Table 6 shows the database tests, indicating the main parameters and results. It must be noted that there is no information regarding the experimental ultimate CFRP jacket hoop strain for several studies. When this information has been published by the actual authors, it has been taken from the original paper. Furthermore, some tests of the database studies have been added, although they are not included by Pham and Hadi (7). The name of the test in Table 6 is the reference number of the database, the original name of the specimen is written only for the tests that have been added.

For the tests displayed in Table 6 containing information on the experimental ultimate CFRP jacket hoop strain, the mean value of the strain efficiency 
TABLE 5. Main parameters and test results of circular specimens tested.

\begin{tabular}{|c|c|c|c|c|c|c|c|c|c|}
\hline & $\begin{array}{c}\text { b } \\
{[\mathrm{mm}]}\end{array}$ & $\begin{array}{c}\mathbf{h} \\
{[\mathrm{mm}]} \\
\end{array}$ & $\begin{array}{c}\mathbf{R}_{\mathbf{c}} \\
{[\mathbf{m m}]}\end{array}$ & $\begin{array}{c}\mathrm{t} \\
{[\mathrm{mm}]}\end{array}$ & $\mathbf{f}_{\mathrm{c}}\left[\mathbf{N} / \mathbf{m m}^{2}\right]$ & $\mathbf{f}_{\mathrm{cc}}\left[\mathbf{N} / \mathbf{m m}^{2}\right]$ & $\mathbf{f}_{\mathrm{cc}} / \mathbf{f}_{\mathrm{c}}$ & $\begin{array}{c}\varepsilon_{\mathrm{fe}} \\
{[\%]}\end{array}$ & $\varepsilon_{\mathrm{fe}} / \varepsilon_{\mathrm{fu}}$ \\
\hline 1_2_20-a & 150 & 150 & 20 & 0.258 & 35.30 & 48.40 & 1.37 & 0.954 & 0.54 \\
\hline 1_2-20-b & 150 & 150 & 20 & 0.258 & 25.10 & 49.70 & 1.98 & 1.158 & 0.65 \\
\hline $1 \_2 \_25-a$ & 150 & 150 & 25 & 0.258 & 25.10 & 55.10 & 2.19 & 1.307 & 0.74 \\
\hline 1_2_25-b & 150 & 150 & 25 & 0.258 & 25.10 & 56.10 & 2.23 & 1.121 & 0.63 \\
\hline 1_3_25 & 150 & 150 & 25 & 0.387 & 34.40 & 72.60 & 2.11 & 1.147 & 0.65 \\
\hline 1_3_30 & 150 & 150 & 30 & 0.387 & 34.40 & 78.10 & 2.27 & 1.259 & 0.71 \\
\hline 1.5_1_20 & 150 & 225 & 20 & 0.129 & 20.20 & 26.00 & 1.28 & 0.954 & 0.54 \\
\hline 1.5_1_25 & 150 & 225 & 25 & 0.129 & 20.20 & 29.80 & 1.47 & 0.659 & 0.37 \\
\hline 1.5_1_30 & 150 & 225 & 30 & 0.129 & 20.20 & 28.40 & 1.40 & 0.686 & 0.39 \\
\hline $1.5 \_2 \_20-b$ & 150 & 225 & 20 & 0.258 & 20.60 & 37.10 & 1.80 & 0.916 & 0.52 \\
\hline $1.5 \_2 \_20-\mathrm{c}$ & 150 & 225 & 20 & 0.258 & 27.10 & 39.10 & 1.44 & 0.915 & 0.52 \\
\hline $1.5 \_2 \_25-\mathrm{a}$ & 150 & 225 & 25 & 0.258 & 20.60 & 37.40 & 1.81 & 1.130 & 0.64 \\
\hline $1.5 \_2 \_25-b$ & 150 & 225 & 25 & 0.258 & 27.10 & 37.80 & 1.40 & 1.118 & 0.63 \\
\hline $1.5 \_2 \_30-b$ & 150 & 225 & 30 & 0.258 & 20.60 & 35.00 & 1.70 & 0.889 & 0.50 \\
\hline $1.5 \_2 \_30-\mathrm{c}$ & 150 & 225 & 30 & 0.258 & 27.10 & 43.20 & 1.59 & 0.934 & 0.53 \\
\hline $1.5 \_3 \_20$ & 150 & 225 & 20 & 0.387 & 34.40 & 44.80 & 1.30 & 0.975 & 0.55 \\
\hline $1.5 \_3 \_25$ & 150 & 225 & 25 & 0.387 & 34.40 & 49.40 & 1.44 & 0.984 & 0.55 \\
\hline $1.5 \_3 \_30$ & 150 & 225 & 30 & 0.387 & 34.40 & 52.40 & 1.52 & 1.010 & 0.57 \\
\hline 2_3_20 & 150 & 300 & 20 & 0.387 & 22.80 & 25.50 & 1.12 & 0.587 & 0.33 \\
\hline 2_3_25 & 150 & 300 & 25 & 0.387 & 22.80 & 27.00 & 1.19 & 0.853 & 0.48 \\
\hline 2_3_30-a & 150 & 300 & 30 & 0.387 & 29.80 & 34.70 & 1.16 & 0.658 & 0.37 \\
\hline 2_3_30-b & 150 & 300 & 30 & 0.387 & 22.80 & 28.60 & 1.26 & 0.799 & 0.45 \\
\hline 2_4_20 & 150 & 300 & 20 & 0.516 & 29.80 & 39.10 & 1.31 & 0.562 & 0.32 \\
\hline 2_4_25 & 150 & 300 & 25 & 0.516 & 29.80 & 40.60 & 1.36 & 0.653 & 0.37 \\
\hline 2_4_30 & 150 & 300 & 30 & 0.516 & 28.10 & 38.00 & 1.35 & 0.713 & 0.40 \\
\hline
\end{tabular}

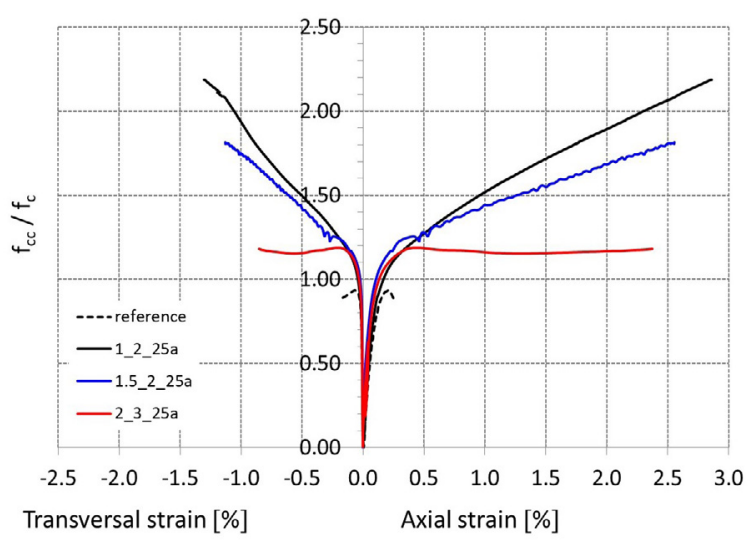

FIGURE 11. Stress-strain curves of specimens with rectangular cross-section. factor for $\mathrm{h} / \mathrm{b}=1$ is 0.56 . Since the confinement stress distribution is non-uniform in the rectangular sections, it is not easy to establish the transversal strain of the jacket, which is a key parameter in strength prediction. For this reason, the following analysis is undertaken by using only the tests of the research project whose CFRP hoop strain has been set following a common criterion (this being the average of the readings of the lateral gauges of the center of each face in the specimen middle-height).

The values of the FRP effective strain obtained from the research project's tests don't fit to any guide recommendation. The Figure 12.a shows the average of the strain efficiency factor $\left(\mathrm{k}_{\varepsilon}\right)$, from the tests with the same $b / h$ and $R_{c}$, versus the ratio radius corner to long side $\left(\mathrm{R}_{\mathrm{c}} / \mathrm{h}\right)$ and its comparison with the TR55 guide proposal, which results conservative for these tests results. There is a general lineal trend, although 
TABLE 6. Main parameters and results of rectangular specimens from database compiled by Pham and Hadi (7).

\begin{tabular}{|c|c|c|c|c|c|c|c|c|c|c|c|}
\hline Test & $\begin{array}{c}\mathbf{b} \\
{[\mathrm{mm}]}\end{array}$ & $\begin{array}{c}\mathbf{h} \\
{[\mathrm{mm}]}\end{array}$ & $\begin{array}{c}\mathbf{R}_{\mathrm{c}} \\
{[\mathbf{m m}]}\end{array}$ & $\begin{array}{c}\mathbf{t} \\
{[\mathrm{mm}]}\end{array}$ & $\begin{array}{c}\mathbf{E}_{\mathbf{f}} \\
{\left[\mathbf{N} / \mathbf{m m}^{2}\right]}\end{array}$ & $\begin{array}{c}\varepsilon_{\mathrm{fu}} \\
{[\%]}\end{array}$ & $\begin{array}{l}\mathbf{f}_{\mathbf{c}}[\mathbf{N} / \\
\left.\mathbf{m m}^{2}\right]\end{array}$ & $\begin{array}{l}\mathbf{f}_{\mathrm{cc}}[\mathbf{N} / \\
\left.\mathbf{m m}^{2}\right]\end{array}$ & $\mathbf{f}_{\mathrm{cc}} / \mathbf{f}_{\mathrm{c}}$ & $\begin{array}{c}\varepsilon_{\mathrm{fe}} \\
{[\%]}\end{array}$ & $\varepsilon_{\mathrm{fe}} / \varepsilon_{\mathrm{fu}}$ \\
\hline 1 & 152 & 152 & 38 & 0.900 & 83000 & 1.50 & 42.00 & 47.50 & 1.13 & 0.71 & 0.47 \\
\hline 2 & 152 & 152 & 25 & 1.200 & 83000 & 1.50 & 43.90 & 50.90 & 1.16 & 0.59 & 0.39 \\
\hline 3 & 152 & 152 & 25 & 1.500 & 83000 & 1.50 & 43.90 & 47.90 & 1.09 & 0.51 & 0.34 \\
\hline 4 & 152 & 152 & 25 & 1.200 & 83000 & 1.50 & 35.80 & 52.30 & 1.46 & 0.70 & 0.47 \\
\hline 5 & 152 & 152 & 25 & 1.500 & 83000 & 1.50 & 35.80 & 57.60 & 1.61 & 0.65 & 0.43 \\
\hline 6 & 152 & 152 & 38 & 1.200 & 83000 & 1.50 & 35.80 & 59.40 & 1.66 & 0.89 & 0.59 \\
\hline 7 & 152 & 152 & 38 & 1.500 & 83000 & 1.50 & 35.80 & 68.70 & 1.92 & 0.86 & 0.57 \\
\hline 50 & 150 & 150 & 25 & 0.165 & 257000 & 1.76 & 33.70 & 39.40 & 1.17 & $1.05^{(\mathrm{a})}$ & $0.60^{(\mathrm{a})}$ \\
\hline 52 & 150 & 150 & 25 & 0.330 & 257000 & 1.76 & 33.70 & 61.90 & 1.84 & $1.08^{(\mathrm{a})}$ & $0.61^{\text {(a) }}$ \\
\hline 54 & 150 & 150 & 25 & 0.495 & 257000 & 1.76 & 24.00 & 66.00 & 2.75 & $1.16^{(\mathrm{a})}$ & $0.66^{(\mathrm{a})}$ \\
\hline S4R25(a) & 150 & 150 & 25 & 0.660 & 257000 & 1.76 & 24.00 & 80.80 & 3.37 & 1.08 & 0.61 \\
\hline S5R25(a) & 150 & 150 & 25 & 0.825 & 257000 & 1.76 & 41.50 & 95.20 & 2.29 & 1.15 & 0.65 \\
\hline 168 & 250 & 250 & 40 & 0.495 & 230000 & 1.50 & 32.80 & 41.40 & 1.26 & $1.21^{(\mathrm{b})}$ & $0.81^{(\mathrm{b})}$ \\
\hline 169 & 250 & 250 & 40 & 0.495 & 230000 & 1.50 & 32.80 & 40.60 & 1.24 & $0.91^{(\mathrm{b})}$ & $0.61^{(\mathrm{b})}$ \\
\hline 170 & 250 & 250 & 40 & 0.825 & 230000 & 1.50 & 32.80 & 56.70 & 1.73 & $1.10^{\text {(b) }}$ & $0.73^{(\mathrm{b})}$ \\
\hline 171 & 250 & 250 & 40 & 0.825 & 230000 & 1.50 & 32.80 & 53.60 & 1.63 & $0.69^{\text {(b) }}$ & $0.46^{(\mathrm{b})}$ \\
\hline 174 & 150 & 150 & 25 & 1.200 & 75000 & 1.25 & 31.80 & 48.30 & 1.52 & - & - \\
\hline 175 & 150 & 150 & 25 & 1.200 & 75000 & 1.25 & 28.50 & 45.60 & 1.60 & - & - \\
\hline 176 & 150 & 150 & 38 & 1.200 & 75000 & 1.25 & 27.70 & 57.00 & 2.06 & - & - \\
\hline 177 & 150 & 150 & 38 & 1.200 & 75000 & 1.25 & 30.30 & 55.00 & 1.82 & - & - \\
\hline 178 & 150 & 150 & 50 & 1.200 & 75000 & 1.25 & 26.70 & 61.70 & 2.31 & - & - \\
\hline 179 & 150 & 150 & 50 & 1.200 & 75000 & 1.25 & 28.30 & 63.70 & 2.25 & - & - \\
\hline 180 & 150 & 150 & 20 & 0.170 & 239000 & 1.87 & 22.00 & 33.50 & 1.52 & - & - \\
\hline 181 & 150 & 150 & 20 & 0.340 & 239000 & 1.87 & 22.00 & 49.60 & 2.25 & - & - \\
\hline 182 & 150 & 150 & 20 & 0.340 & 239000 & 1.87 & 19.50 & 47.20 & 2.42 & - & - \\
\hline 183 & 150 & 150 & 35 & 0.340 & 239000 & 1.87 & 22.00 & 64.80 & 2.95 & - & - \\
\hline 184 & 150 & 150 & 35 & 0.340 & 239000 & 1.87 & 19.50 & 58.70 & 3.01 & - & - \\
\hline 185 & 150 & 150 & 50 & 0.340 & 239000 & 1.87 & 22.00 & 76.60 & 3.48 & - & - \\
\hline 186 & 150 & 150 & 50 & 0.340 & 239000 & 1.87 & 19.50 & 63.60 & 3.26 & - & - \\
\hline 187 & 150 & 150 & 20 & 0.170 & $241000^{(\mathrm{c})}$ & 1.74 & 49.50 & 54.20 & 1.09 & - & - \\
\hline 188 & 150 & 150 & 20 & 0.340 & $241000^{(\mathrm{c})}$ & 1.74 & 49.50 & 61.40 & 1.24 & - & - \\
\hline 189 & 150 & 150 & 35 & 0.340 & $241000^{(\mathrm{c})}$ & 1.74 & 49.50 & 84.90 & 1.72 & - & - \\
\hline 190 & 150 & 150 & 50 & 0.340 & $241000^{(\mathrm{c})}$ & 1.74 & 49.50 & 86.10 & 1.74 & - & - \\
\hline R4R25 (a) & 150 & 225 & 25 & 0.660 & 257000 & 1.76 & 41.50 & 51.90 & 1.25 & 0.74 & 0.42 \\
\hline LS1.5-1-20 (c) & 150 & 230 & 20 & 0.170 & 239000 & 1.87 & 22.00 & 23.60 & 1.07 & - & - \\
\hline LS1.5-2-20(c) & 150 & 230 & 20 & 0.340 & 239000 & 1.87 & 22.00 & 33.20 & 1.51 & - & - \\
\hline LS1.5-2-35(c) & 150 & 230 & 35 & 0.340 & 239000 & 1.87 & 22.00 & 40.70 & 1.85 & - & - \\
\hline LS1.5-2-50(c) & 150 & 230 & 50 & 0.340 & 239000 & 1.87 & 22.00 & 46.70 & 2.12 & - & - \\
\hline LS2-1-20(c) & 150 & 300 & 20 & 0.170 & 239000 & 1.87 & 19.50 & 21.80 & 1.12 & - & - \\
\hline LS2-2-20(c) & 150 & 300 & 20 & 0.340 & 239000 & 1.87 & 19.50 & 23.60 & 1.21 & - & - \\
\hline LS2-2-35 (c) & 150 & 300 & 35 & 0.340 & 239000 & 1.87 & 19.50 & 30.90 & 1.58 & - & - \\
\hline LS2-2-50 (c) & 150 & 300 & 50 & 0.340 & 239000 & 1.87 & 19.50 & 34.80 & 1.78 & - & - \\
\hline NS2-2-50 ${ }^{(\mathrm{c})}$ & 150 & 300 & 50 & 0.340 & 241000 & 1.74 & 49.50 & 54.10 & 1.09 & - & - \\
\hline NS2-2-20 (c) & 150 & 300 & 20 & 0.340 & 241000 & 1.74 & 49.50 & 52.40 & 1.06 & - & - \\
\hline
\end{tabular}

(a) The data have been taken from the original paper published by Lam and Teng (17).

(b) The data have been taken from the original paper published by Ilki and Kumbasar (5).

(c) The data have been taken from the original paper published by Tao et al. (6). 


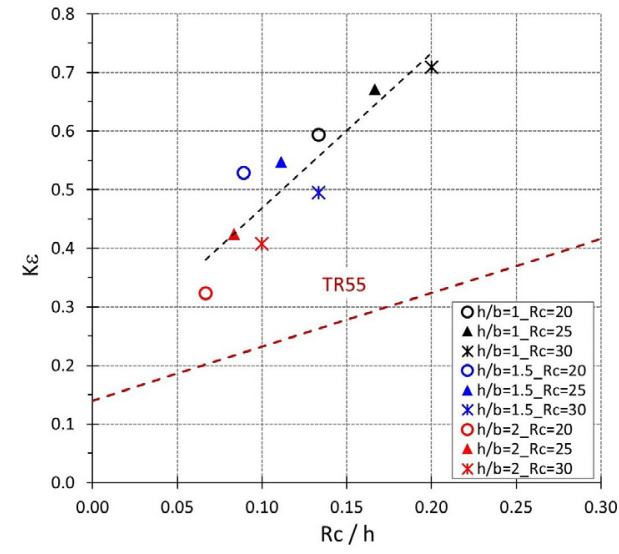

a)

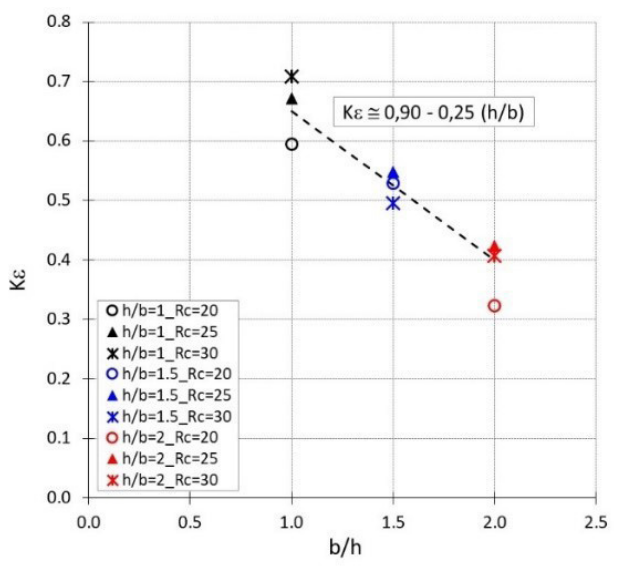

b)

FigURE 12. Average of the strain efficiency factor $\left(\mathrm{k}_{\varepsilon}\right)$ versus to: $\left.a\right)$ the ratio radius corner to long side $\left(\mathrm{R}_{\mathrm{c}} / \mathrm{h}\right)$ and $\left.\mathrm{b}\right)$ the side-aspect ratio $(\mathrm{b} / \mathrm{h})$.

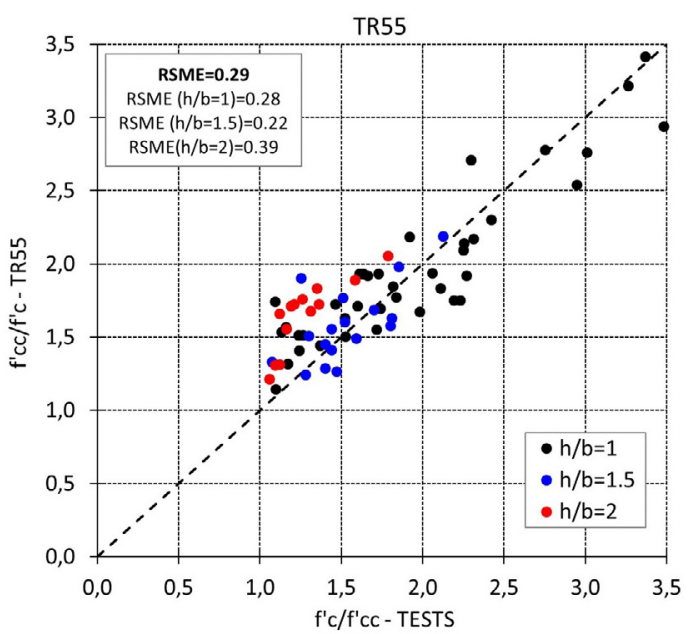

a)

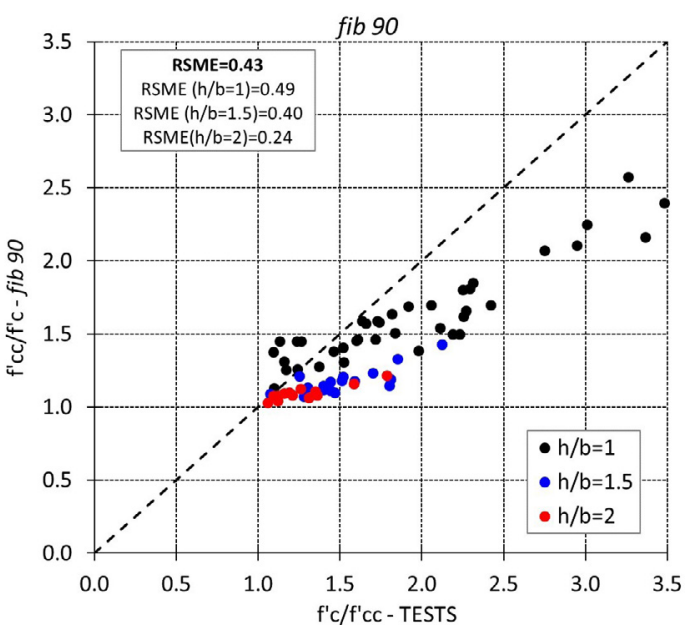

c)

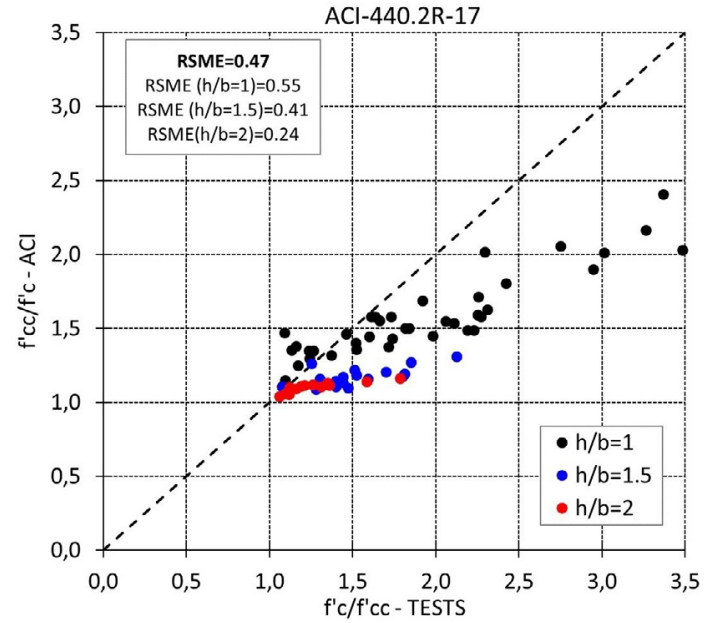

b)

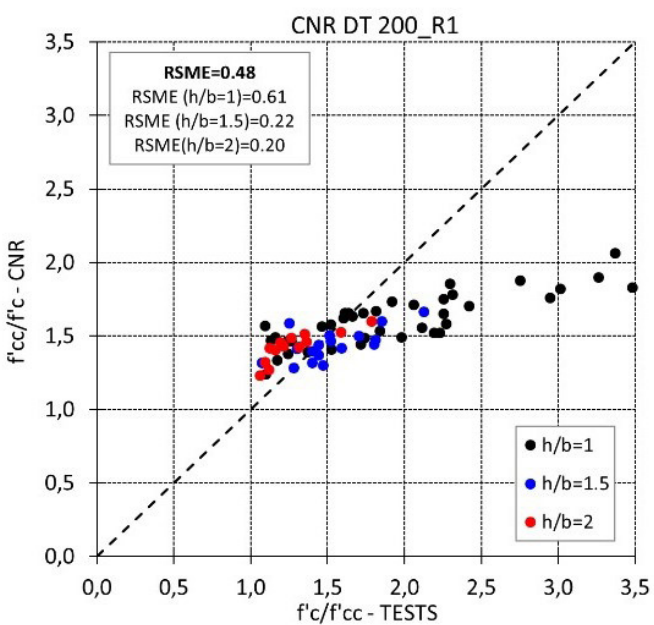

d)

FigURE 13. Experimental strength enhancement ratio vs predicted values by guidelines. 


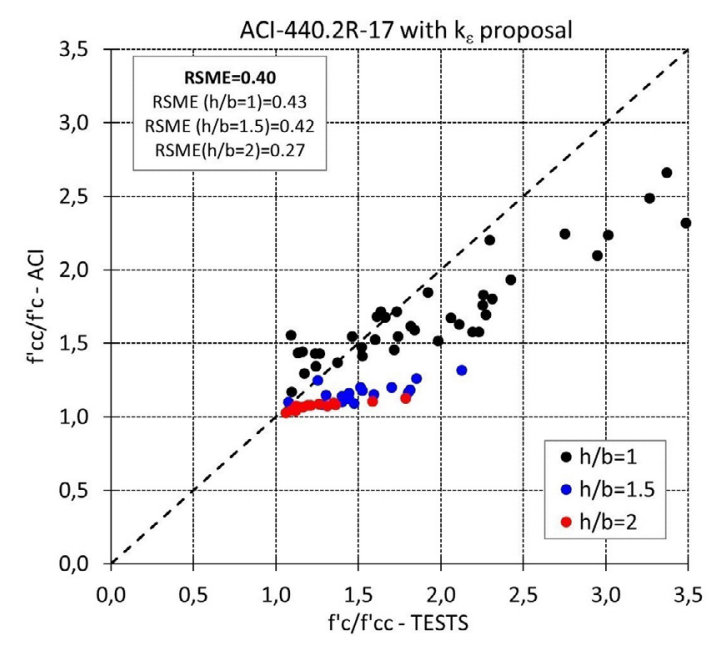

a)

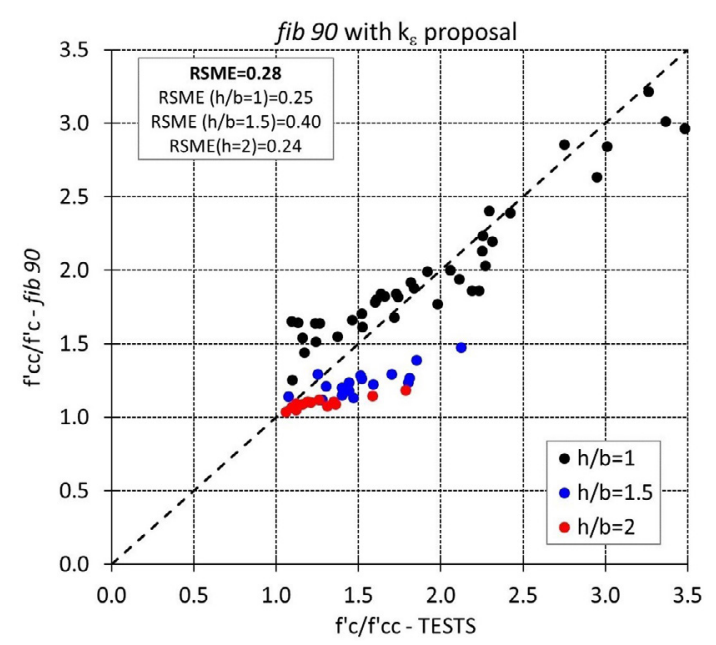

b)

FIGURE 14. Strength enhancement ratio vs prediction by ACI and fib 90 guides with the proposal of $\mathrm{k}_{\varepsilon}$.

with certain dispersion. For square section specimens, a higher strain efficiency factor has been obtained when the corner radius is larger, yet for rectangular ones a larger radius has not always led to a higher $\mathrm{k}_{\varepsilon}$.

On the other hand, the strain efficiency factor seems highly conditioned to the side-aspect rate, Figure 12.b. It is observed the lineal trend of Equation [5]. This trend is obtained from the research project's tests ( $\mathrm{R}_{\mathrm{c}}$ equal to 20,25 and $30 \mathrm{~mm}$ ) and it would correspond to the average value of $\mathrm{R}_{\mathrm{c}}$ equal to $25 \mathrm{~mm}$.

$$
\mathrm{k}_{\varepsilon} \cong(0.90-0.25 \mathrm{~h} / \mathrm{b})
$$

This linear fit is modulated to take into account the different strength improvement due to the corner radius, which is usually between 20 and $50 \mathrm{~mm}$ for real applications. A strength improvement of $10 \%$ higher is considered for the larger corner radius regards to the smaller one. This would provide the resulting equation shown below, Equation [6].

$$
\begin{aligned}
& \mathrm{k}_{\varepsilon} \cong(0.90-0.25 \mathrm{~h} / \mathrm{b})\left(1+\left(\mathrm{R}_{\mathrm{c}}-25\right) / 300\right) \\
& \text { for } 20 \mathrm{~mm} \geq \mathrm{R}_{\mathrm{c}} \leq 50 \mathrm{~mm}
\end{aligned}
$$

\subsection{Confined concrete strength in rectangular specimens strengthened with CFRP jackets}

Equally, with regard to circular specimens, the results of rectangular cross-section tests included in the Table 5 and Table 6 have been compared with the theoretical predictions by the four international guides (13-16). There are a total of 69 experimental results: 39 of square section ( 6 of the research project), 17 of rectangular section with $\mathrm{b} / \mathrm{h}=1.5$ (12 of the research project) and 13 of rectangular section with $\mathrm{b} / \mathrm{h}=2$ (7 of the research project).

The graph showing the comparison between the experimental results and the theoretical predictions by each guide are displayed in Figure 13, indicating the root mean square error (RMSE) that is interpreted only comparatively. No partial safety factors of materials have been used to obtain these predictions.

In order to compare the different models, no limitations contained in the guides have been used. This means that the predictions of specimens with aspect ratio of 2 by using TR55 formulation have been included. For those that fail to meet the fib 90' minimum ratio condition, no strength enhancement should be expected according to this guide. Still, these tests entailed strength gain, meaning that the limitation does not apply.

The TR55 predictions adapt more suitably to the general trend followed by the experimental results, except for $h / b=2$, which is consistent with the fact that this guide excludes this proportion from the sides. The CNR is better suited for rectangular tests with b/ $\mathrm{h}=1.5$ and 2 . The others present a similar degree of adjustment.

The Figure 14 shows the comparison of the two guides based on the simple linear adjustment, ACI and fib 90, by using the $\mathrm{k}_{\varepsilon}$ proposal, Equation [6]. The $f i b 90$ guide' predictions is improved somewhat. As mentioned before, the transversal strain attained in the FRP jacket at failure is a key parameter in strength prediction.

\section{CONCLUSIONS}

This paper deals with the behavior of carbon FRP-confined concrete columns, mainly, with square and rectangular cross-section. The results of a research project's experimental program carried out on intermediate-size plain concrete specimens with square, rectangular and circular section are compared to others of similar characteristics contained in two published databases $(3,7)$. 
An overview of the approach of four international guides (ACI-440.2R-17, TR55, fib 90, CNR-DT200 $\mathrm{R} 1)$ to predict the strength gain obtained for concrete members with FRP reinforcement is presented. Their proposals differ, among others, on two key issues: the effect of confinement in non-circular sections and the effective strain in the FRP jacket at failure. The strength predictions by using the four guidelines were found to diverge mutually, especially, in the case of rectangular cross-section columns.

As reported by other researchers, the ultimate hoop CFRP strain of the jackets in the circular section specimens were lower than the ultimate strain obtained in tensile coupon tests. An average value of the strain efficiency factor $\left(\varepsilon_{\mathrm{fe}} / \varepsilon_{\mathrm{fu}}\right)$ equal to 0.73 was obtained from the circular test database and the research program.

The value of the strain efficiency factor $\left(\varepsilon_{\mathrm{fe}} / \varepsilon_{\mathrm{fu}}\right)$ was found to decrease with an increase in the side-aspect ratio for rectangular sections. An average value of 0.65 was obtained in the research program's square specimens, while in the rectangular specimens with aspect ratio of 1.5 and 2 the average value was 0.52 and 0.39 .

The values of the FRP effective strain $\left(\varepsilon_{\mathrm{fe}}\right)$ from the research project's square and rectangular tests don't fit to the guides recommendations. The lateral strain attained in the FRP jacket at failure is a key parameter in strength prediction. An expression is proposed to calculate the strain efficiency factor $\left(\varepsilon_{\mathrm{fe}} / \varepsilon_{\mathrm{fu}}\right)$ which depends, mainly, on the side-aspect ratio $(b / h)$ and, to a lesser extent, on the corner radius $\left(\mathrm{R}_{c}\right)$. The prediction of the ACI and $f i b$ guides, based on a simple linear design-model, improves by using the efficiency strain factor proposed for rectangular sections.

Further experimental investigation is deemed necessary to improve the estimation of effective ultimate strain of the FRP as a function of aspect ratio and corner radius of rectangular cross-section columns.

The above conclusions should be considered within the scope of the parameters under study (intermediate-size specimens, non-slender columns, fully wrapping of carbon FRP, unconfined concrete strength not higher than $50 \mathrm{~N} / \mathrm{mm}^{2}$ ) and with the limitations derived from the number of the available tests.

\section{ACKNOWLEDGMENTS}

This work is part of research project BIA201680310-P, funded by the Spanish Research Agency (AEI) and the European Regional Development Fund (ERDF). V.J. Castro acknowledges the financial support (FPI grant BES2017-080647) of the Spanish MICINN and the European Social Fund. S. Martínez acknowledges the financial support of Project PIE-202060E267 funded by the Spanish National Research Council. The experimental program has been carried out in the Mechanical Laboratory of the Eduardo Torroja Institute for Construction Science
(IETcc, CSIC). The authors are grateful to the laboratory staff for their collaboration.

The authors are grateful to SIKA S.A for supplying the FRP material and to the Technological Institute of Aragon (ITAINNOVA) for their collaboration in the numerical model based on the finite element method (FEM).

\section{AUTHOR CONTRIBUTIONS:}

Conceptualization: J.P. Gutiérrez. Data curation: A. de Diego, V. J. Castro. Formal analysis: J.P. Gutiérrez, S. Martínez. Funding acquisition: J.P. Gutierrez, A. de Diego. Investigation: J.P. Gutiérrez, S. Martínez, A. de Diego, V. J. Castro, L. Echevarría. Methodology: J.P. Gutiérrez. Project administration: J.P. Gutiérrez. Resources: J.P. Gutiérrez. Software: J.P. Gutierrez, L. Echevarría. Supervision: J. P. Gutierrez. Validation: A. de Diego, V. J. Castro, L. Echevarría. Visualization: S. Martínez. Roles/Writing, original draft: S. Martínez; Writing - review \& editing: S. Martínez.

\section{REFERENCES}

1. Siddika, A.; Al Mamun, M.A.; Ferdous, W.; Alyousef, R. (2020) Performances, challenges and opportunities in strengthening reinforced concrete structures by using FRPs-A state-of-the-art review. Eng. Fail. Anal. 111, 104480. https:// doi.org/10.1016/j.engfailanal.2020.104480.

2. De Lorenzis, L.; Tepfers, R. (2003) Comparative study of models on confinement of concrete cylinders with fiber-reinforced polymer composites. J. Comp. Construc. 7, 219-237. https://doi. org/10.1061/(ASCE)1090-0268(2003)7:3(219).

3. Ozbakkaloglu, T.; Lim, J.C. (2013) Axial compressive behavior of FRP-confined concrete: Experimental test database and a new design-oriented model. Compos. Part B. Eng. 55, $607-$ 634. https://doi.org/10.1016/j.compositesb.2013.07.025.

4. Mirmiran, A.; Shahawy, M.; Samaan, M.; El Echary, H.; Mastrapa, J.C.; Pico, O. (1998) Effect of column parameters on FRP-confined concrete. J. Compos Constr. 2 [4], 175-185. https://doi.org/10.1061/(ASCE)1090-0268(1998)2:4(175).

5. Ilki, A.; Kumbasar, N. (2003) Compressive behaviour of carbon fibre composite jacketed concrete with circular and non-circular cross-sections. J. Earthq. Eng. 7 [03], 381-406. https://www.worldscientific.com/doi/10.1142/ S1363246903001140.

6. Tao, Z.; Yu, Q.; Zhong, Y-Z. (2008) Compressive behaviour of CFRP-confined rectangular concrete columns. Mag. Concr. Res. 60 [10], 735-745. https://doi.org/10.1680/ macr.2007.00115

7. Pham, T.M.; Hadi, M.N. (2014) Stress prediction model for FRP confined rectangular concrete columns with rounded corners. J. Comp. Construc. 18 [1], 04013019. https://doi. org/10.1061/(ASCE)CC.1943-5614.0000407.

8. De Diego, A.; Arteaga, A.; Fernández, J. (2019) Strengthening of square concrete columns with composite materials. Investigation on the FRP jacket ultimate strain. Compos. Part B. Eng. 162, 454-460. https://doi.org/10.1016/j. compositesb.2019.01.017.

9. Nisticò, N.; Monti, G. (2013) RC square sections confined by FRP: Analytical prediction of peak strength. Compos. Part B. Eng. 45 [1], 127-137. https://doi.org/10.1016/j. compositesb.2012.09.041.

10. Spoelstra, M.R.; Monti, G. (1999) FRP-confined concrete model. J. Comp. Construc. 3 [3], 143-150. https://doi. org/10.1061/(ASCE)1090-0268(1999)3:3(143).

11. Lin, G.; Teng, J.G. (2020) Advanced stress-strain model for FRP-confined concrete in square columns. Compos. Part B. Eng. 197, 108149. https://doi.org/10.1016/j. compositesb.2020.108149.

12. Shayanfar, J.; Barros, J.; Rezazadeh, M. (2021) Generalized Analysis-oriented model of FRP confined concrete circular 
columns. Compos. Struct. 270, 114026. https://doi. org/10.1016/j.compstruct.2021.114026.

13. American Concrete Institute (2017) ACI-440.2R-17, Guide for the design and construction of externally bonded FRP systems for strengthening concrete structures, Farmington Hills, Michigan.

14. Concrete Society (2012) TR55 Technical Report Design guidance for strengthening concrete structures using fibre composite materials, 3rd edition, UK.

15. Fédération internationale du béton (2019) fib Bulletin 90, Externally bonded FRP reinforcement for RC structures. fib, Lausanne, Switzerland.
16. National Research Council, Advisory Committee on Technical Recommendations for Construction (2013) CNR-DT200 R1. Guide for the design and construction of externally bonded FRP systems for strengthening existing structures, Italy.

17. Lam, L.; Teng, J.G. (2003) Design-oriented stress-strain model for FRP-confined concrete in rectangular columns. J. Reinf. Plast. Compos. 22, 1149-1186. https://doi. org/10.1177\%2F0731684403035429.

18. Teng, J.G.; Jiang, T.; Lam, L.; Luo, Y.Z. (2009) Refinement of a design-oriented stress-strain model for FRP-confined concrete. J. Compos. Constr. 13, 269-278. https://doi. org/10.1061/(ASCE)CC.1943-5614.0000012. 